\title{
Spatial and temporal variability in the response of phytoplankton and prokaryotes to B-vitamin amendments in an upwelling system
}

\author{
Vanessa Joglar, Antero Prieto, Esther Barber-Lluch, Marta Hernández-Ruiz, Emilio Fernández, and Eva Teira \\ Centro de Investigación Mariña da Universidade de Vigo (CIM-UVigo), Departamento Ecoloxía e Bioloxía Animal, \\ Universidade de Vigo, Campus Lagoas-Marcosende, Vigo, 36310, Spain
}

Correspondence: Vanessa Joglar (vjoglar@uvigo.es)

Received: 7 August 2019 - Discussion started: 22 August 2019

Revised: 3 April 2020 - Accepted: 22 April 2020 - Published: 26 May 2020

\begin{abstract}
We experimentally evaluated the temporal (interday and interseason) and spatial variability in microbial plankton responses to vitamin B12 and/or B1 supply (solely or in combination with inorganic nutrients) in coastal and oceanic waters of the northeast Atlantic Ocean. Phytoplankton and, to a lesser extent, prokaryotes were strongly limited by inorganic nutrients. Interday variability in microbial plankton responses to B vitamins was limited compared to interseason variability, suggesting that B-vitamin availability might be partially controlled by factors operating at seasonal scale. Chlorophyll $a(\mathrm{Chl} a)$ concentration and prokaryote biomass (PB) significantly increased after Bvitamin amendments in $13 \%$ and $21 \%$, respectively, of the 216 cases (36 experiments $\times 6$ treatments). Most of these positive responses were produced by treatments containing either B12 solely or B12 combined with B1 in oceanic waters, which was consistent with the significantly lower average vitamin-B12 ambient concentrations compared to that in the coastal station. Negative responses, implying a decrease in Chl $a$ or PB, represented $21 \%$ for phytoplankton and $26 \%$ for prokaryotes. Growth stimulation by B1 addition was more frequent on prokaryotes than in phytoplankton, suggesting that B1 auxotrophy in the sampling area could be more widespread in prokaryotes than in phytoplankton. Negative responses to B vitamins were generalized in coastal surface waters in summer and were associated with a high contribution of Flavobacteriales to the prokaryote community. This observation suggests that the external supply of B12 and/or B1 may promote negative interactions between microbial components when B-vitamin auxotrophs are abundant. The microbial response patterns to B12 and/or
\end{abstract}

B1 amendments were significantly correlated with changes in the prokaryotic community composition, highlighting the pivotal role of prokaryotes in B-vitamin cycling in marine ecosystems.

\section{Introduction}

Phytoplankton accounts for almost half of the global net primary production (Field et al., 1998) and may eventually cause toxic episodes, such as those caused by harmful algae blooms of Alexandrium spp. or Gymnodinium spp., entailing human health problems and large economic losses (Hallegraeff, 1993; van Dolah et al., 2001). Recent emerging evidence suggests the role of biologically active organic compounds, such as B vitamins, on the control of marine productivity in both coastal and oceanic waters (Panzeca et al., 2006; Bertrand et al., 2007; Gobler et al., 2007; Koch et al., 2011; Browning et al., 2017, 2018). B vitamins act as cofactors for enzymatic reactions and are involved in many important metabolic pathways (Madigan et al., 2005; Koch et al., 2011; Monteverde et al., 2017). Vitamin B12 (B12 herein), which is exclusively synthesized by some bacteria and archaea (Roth et al., 1996; Martens et al., 2002; Warren et al., 2002), acts as a cofactor of three enzymes in eukaryotes (methionine synthase, methylmalonyl-coA mutase and ribonucleotide reductase type II) (Helliwell et al., 2011; Bertrand and Allen, 2012). In comparison, over 20 different B12-dependent enzymes are found in bacteria (Roth et al., 1996), making B12 critically important also for these organ- 
isms. Vitamin B1 (B1 herein) plays a pivotal role in intermediary carbon metabolism and is a cofactor for a number of enzymes involved in primary carbohydrate and branchedchain amino acid metabolism (Croft et al., 2006).

Most eukaryote phytoplankton species are auxotrophs for one or more B vitamins, consequently requiring an exogenous supply of these molecules (Bertrand and Allen, 2012; Carlucci and Bowes, 1970; Haines and Guillard, 1974; Helliwell et al., 2011). Moreover, genomic data also indicate widespread B-vitamin auxotrophy among many bacterial taxonomic groups (Sañudo-Wilhelmy et al., 2014; Paerl et al., 2018), which implies that phytoplankton and bacterioplankton may eventually compete for the acquisition of these compounds (Koch et al., 2012). Auxotrophic microorganisms may acquire the required vitamins from the environment or through biotic interactions with prototrophic (biosynthetically competent) microorganisms (Droop, 2007; Grant et al., 2014; Kazamia et al., 2012). A well-known example is the mutualistic interaction between B12 and/or B1auxotrophic phytoplankton and vitamin-producing bacteria (Croft et al., 2005; Amin et al., 2012; Cooper and Smith, 2015; Cruz-López and Maske, 2016).

Even though B vitamins appear to be important and potentially limiting factors for microbial plankton, our understanding of B-vitamin cycling in the ocean is largely limited by the complex and still-evolving analytical methodology for its quantification in natural waters (Okbamichael and Sañudo-Wilhelmy, 2004, 2005; Suffridge et al., 2017). Sañudo-Wilhelmy et al. (2012) found extensive areas of coastal waters with close to undetectable B12 concentrations, suggesting that microbes might be well adapted to thrive under limiting conditions for this growth factor.

The factors limiting phytoplankton and bacterial growth in marine ecosystems are known to vary over different spatial and temporal scales (Cullen et al., 1992; Arrigo, 2005; Martínez-García et al., 2010b; Moore et al., 2013), in accordance with the dynamic nature of microbial communities (Pinhassi et al., 2003; Fuhrman et al., 2008; HernandoMorales et al., 2018). Compared to mineral nutrient and trace elements, much less is known about B-vitamin limitation and its spatial and temporal variability in marine ecosystems.

Some studies have shown enhanced phytoplankton biomass associated with B12 amendments in both temperate coastal and polar waters (Bertrand et al., 2007; Gobler et al., 2007; Koch et al., 2011, 2012). The simultaneous effect of vitamin-B12 supply on both phytoplankton and bacteria has been barely explored (Koch et al., 2011, Barber-Lluch et al., 2019). To our knowledge, the effect of B1 amendments on marine natural microbial plankton community succession has been only assessed by Gobler et al. (2007), who suggested that high concentration of B vitamins, associated with high bacterial abundance, caused an increase in auxotrophs, mostly dinoflagellates.

The Ría de Vigo (NW Spain) is a coastal embayment affected by intermittent upwelling of subsurface cold and inorganic-nutrient-rich water from March to September and the downwelling of open-ocean surface water from October to March (Fraga, 1981; Barton et al., 2015). In addition to this seasonality, fluctuations of wind patterns in the area generate upwelling and downwelling events occurring within each season (Alvarez-Salgado et al., 1993; Figueiras et al., 2002). A recent study by Barber-Lluch et al. (2019) at a shelf station off the Ría de Vigo (NW Spain) showed monthly variation in the response of phytoplankton and bacteria to nutrient and/or B12 additions in surface waters, likely related to variation in the ambient concentration of B12 and the taxonomic community composition. Unfortunately, these authors did not specifically assess the role of these factors on the microbial response to the amendments.

Within this context, the aim of our study was to explore spatial (horizontal and vertical) and temporal (interday and interseason) variability patterns in B12- and B1-vitamin limitation in relation to the prevailing initial abiotic (e.g., nutrient and B12 concentrations) and biotic (eukaryote and prokaryote community composition) conditions in this productive ecosystem. We conducted a total of 36 microcosm bioassays in February, April and August 2016 to evaluate the response of heterotrophic bacteria and phytoplankton biomasses to the addition of B12 and/or B1.

Considering that a large fraction of eukaryotic phytoplankton and bacterial taxa require exogenous B vitamins and considering the different requirements and capabilities to synthesize B vitamins by different microbial taxa, we hypothesize that microbial community composition plays a relevant role in explaining B-vitamin limitation patterns in microbial plankton.

\section{Methods}

\subsection{Sampling strategy}

Thirty-six enrichment experiments were performed in the upwelling system near Ría de Vigo on board B/O Ramón Margalef in three different oceanographic cruises (ENVISION I, II and III) conducted in 2016. Two different locations of the east Atlantic Ocean, one coastal station $(\mathrm{C})\left(42^{\circ} \mathrm{N}, 8.88^{\circ} \mathrm{W}\right)$ and one oceanic station $(\mathrm{Oc})\left(42^{\circ} \mathrm{N}, 9.06^{\circ} \mathrm{W}\right)($ Fig. 1a), were sampled during three different seasons aimed to cover a wide range of initial hydrographic and ecological conditions. The $10 \mathrm{~d}$ cruises were conducted in February (ENVISION I), coinciding with the spring bloom, and in April (ENVISION II) and August (ENVISION III) during the early and late summer upwelling, respectively. During each cruise, 12 enrichment experiments were carried out on board, 3 experiments in each station $(\mathrm{C}-\mathrm{a}, \mathrm{C}-\mathrm{b}$ and $\mathrm{C}-\mathrm{c}$ as well as Oc-a, Oc-b and Oc-c, respectively) with water from two different depths. Each experiment began on the first (day 0), third (day 2) and sixth (day 5) of each cruise for the coast and on the second (day 1), fourth (day 3) and seventh (day 6) of each 
cruise for the ocean (Fig. 1b, c). Water was collected using 20 L Niskin metal-free bottles. Surface $(5 \mathrm{~m})$ and subsurface chlorophyll maximum (SCM) (between 10 and $50 \mathrm{~m}$ according to the conductivity, temperature and depth (CTD) data) samples were taken (Fig. 2a-f). We failed to sample the SCM on two occasions (C-a in February and C-a in April), due to large vertical displacements between the downward and the upward casts. Vertical profiles of temperature, salinity and chlorophyll fluorescence were obtained using a regular stainless CTD rosette down to $60 \mathrm{~m}$ in the coastal station and to $200 \mathrm{~m}$ in oceanic station. Samples for chlorophyll $a(\mathrm{Chl} a)$; prokaryotic biomass (PB); dissolved nutrient concentration, including vitamin B12; and microbial plankton community were collected at the beginning (time zero, hereafter referred to as $t 0$ ) of each enrichment experiment. Daily upwelling index (UI) values were computed by the Instituto Español de Oceanografía (http://www.indicedeafloramiento.ieo.es/, last access: 20 July 2019) in a $2^{\circ} \times 2^{\circ}$ geostrophic cell centered at $42^{\circ} \mathrm{N}, 10^{\circ} \mathrm{W}$, using data from atmospheric pressure at sea level, derived from the WXMAP model (GonzalezNuevo et al., 2014). Precipitation data were obtained from the Regional Weather Forecast Agency, Meteogalicia (http: //www.meteogalicia.gal, last access: 20 July 2019), in the meteorological station Illas Cíes (ID 10125).

\subsection{Experimental design}

Seawater samples were gently prefiltered through a $200 \mu \mathrm{m}$ mesh to exclude large zooplankton in order to ensure good replicability and collected into a $20 \mathrm{~L}$ acid-cleaned polyethylene carboy. It is important to note that incidental tracemetal contamination could have occurred during water collection. Following sample collection, $300 \mathrm{~mL}$ PAR (photosynthetically active radiation) and UVR (ultraviolet radiation) transparent, sterile and nontoxic (Whirl-Pak) bags were filled, and nutrients were added establishing eight different enrichment treatments as follows: (1) control treatment (C), (2) inorganic-nutrient treatment (I), (3) vitaminB12 (Sigma, V2876) treatment, (4) vitamin-B1 (Sigma, T4625) treatment, (5) inorganic-nutrient and vitamin-B12 (I+B12) treatment, (6) inorganic-nutrient and vitamin-B1 $(\mathrm{I}+\mathrm{B} 1)$ treatment, (7) vitamin-B12 and $\mathrm{B} 1(\mathrm{~B} 12+\mathrm{B} 1)$ treatment, and (8) inorganic-nutrient and vitamin-B12 and $\mathrm{B} 1(\mathrm{I}+\mathrm{B} 12+\mathrm{B} 1)$ treatment (see Table 1 for details). Inorganic nutrients were added to avoid that inorganic-nutrient limitation masked the responses to B vitamins. The nutrient concentrations of the additions were the same as previously used in similar enrichment experiments in the sampling area (Martínez-García et al., 2010a). The amount of B12 and B1 vitamins experimentally added approximated maximum concentrations previously observed in coastal areas (Okbamichael and Sañudo-Wilhelmy 2004, 2005; SañudoWilhelmy et al., 2006). Each treatment had three replicates resulting in 24 Whirl-Pak bags per experiment. To assess short-term effects of nutrient inputs, experimental bags were
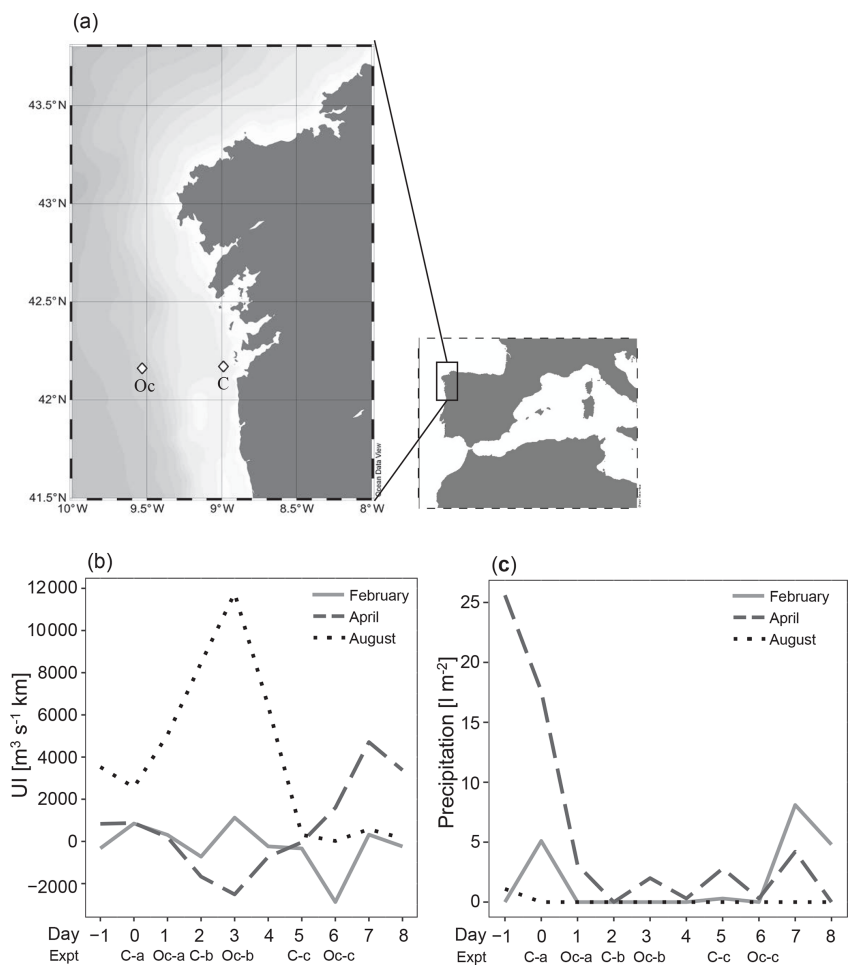

Figure 1. (a) The NW Iberian margin (rectangle) and locations of the stations that were sampled in the Ría de Vigo (C) and on the shelf (Oc) (diamonds), (b) distribution of daily coastal upwelling index (UI), and (c) registered precipitations during each sampling period showing the initial time of each experiment (C-a, C-b and $\mathrm{C}-\mathrm{c}$ as well as Oc-a, Oc-b and Oc-c).

incubated on deck during $72 \mathrm{~h}$. In-situ temperature was reproduced by submerging the bags in tanks filled with constantly circulating surface seawater. To simulate light intensity at the SCM, the incident light was attenuated by covering the tanks with mesh screens.

\subsection{Chlorophyll $a$}

Chlorophyll $a(\mathrm{Chl} a)$ concentration was measured at $t 0$ and after $72 \mathrm{~h}$ incubation as a phytoplankton biomass proxy. A volume of $300 \mathrm{~mL}$ of water samples was filtered through $0.2 \mu \mathrm{m}$ polycarbonate filters. The filters were immediately frozen at $-20^{\circ} \mathrm{C}$ until further analysis. Chl $a$ was extracted with $90 \%$ acetone and kept in darkness at $4{ }^{\circ} \mathrm{C}$ overnight. Fluorescence was determined with a TD-700 Turner Designs fluorometer calibrated with pure Chl $a$ standard solution (absorption coefficient at $663 \mathrm{~nm}=87.7$; Lorenzen and Newton Downs, 1986).

\subsection{Flow cytometry}

Samples for prokaryote abundance quantification $(2 \mathrm{~mL})$ were preserved with $1 \%$ paraformaldehyde $+0.05 \%$ glutaraldehyde (final concentrations). Samples were incubated 
Table 1. Eight different treatments were applied consisting of the (1) control treatment (C): no nutrients added; (2) inorganic (I) nutrient treatment: $5 \mu \mathrm{M}$ nitrate $\left(\mathrm{NO}_{3}^{-}\right), 5 \mu \mathrm{M}$ ammonium $\left(\mathrm{NH}_{4}^{+}\right), 5 \mu \mathrm{M}$ silicate $\left(\mathrm{SiO}_{4}^{2-}\right)$ and $1 \mu \mathrm{M}$ phosphate $\left(\mathrm{HPO}_{4}^{2-}\right)$; (3) vitamin-B12 treatment: $100 \mathrm{pmol} \mathrm{L}^{-1}$; (4) vitamin-B1 treatment: $600 \mathrm{pmol} \mathrm{L}^{-1}$ ); (5) inorganic-nutrient and vitamin-B12 $(\mathrm{I}+\mathrm{B} 12)$ treatment; (6) inorganic-nutrient and vitamin-B1 (I + B1) treatment; (7) vitamin-B12 and B1 $(\mathrm{B} 12+\mathrm{B} 1)$ treatment; and (8) inorganic-nutrient and vitamin-B12 and $\mathrm{B} 1(\mathrm{I}+\mathrm{B} 12+\mathrm{B} 1)$ treatment.

\begin{tabular}{|c|c|c|}
\hline Treatment & Nutrient included & Concentration \\
\hline 1. Control (C) & No nutrient added & \\
\hline 2. Inorganic nutrients (I) & $\begin{array}{l}\mathrm{NO}_{3}^{-} \\
\mathrm{NH}_{4}^{+} \\
\mathrm{HPO}_{4}^{2-} \\
\mathrm{SiO}_{4}^{2-}\end{array}$ & $\begin{array}{l}5 \mu \mathrm{mol} \mathrm{L}^{-1} \\
5 \mu \mathrm{mol} \mathrm{L}-1 \\
1 \mu \mathrm{mol} \mathrm{L}-1 \\
5 \mu \mathrm{mol} \mathrm{L}^{-1}\end{array}$ \\
\hline 3. Vitamin B12 (B12) & B12 & $100 \mathrm{pmol} \mathrm{L}^{-1}$ \\
\hline 4. Vitamin B1 (B1) & B1 & $600 \mathrm{pmol} \mathrm{L}^{-1}$ \\
\hline 5. $\mathrm{B} 12+\mathrm{B} 1$ & $\begin{array}{l}\text { B12 } \\
\text { B1 }\end{array}$ & $\begin{array}{l}100 \mathrm{pmol} \mathrm{L}^{-1} \\
600 \mathrm{pmol} \mathrm{L}^{-1}\end{array}$ \\
\hline $6 . \mathrm{I}+\mathrm{B} 12$ & $\begin{array}{l}\mathrm{NO}_{3}^{-} \\
\mathrm{NH}_{4}^{+} \\
\mathrm{HPO}_{4}^{2-} \\
\mathrm{SiO}_{4}^{2-} \\
\mathrm{B} 12\end{array}$ & $\begin{array}{l}5 \mu \mathrm{mol} \mathrm{L}-1 \\
5 \mu \mathrm{mol} \mathrm{L}-1 \\
1 \mu \mathrm{mol} \mathrm{L}-1 \\
5 \mu \mathrm{mol} \mathrm{L}-1 \\
100 \mathrm{pmol} \mathrm{L}^{-1}\end{array}$ \\
\hline 7. I+ B1 & $\begin{array}{l}\mathrm{NO}_{3}^{-} \\
\mathrm{NH}_{4}^{+} \\
\mathrm{HPO}_{4}^{2-} \\
\mathrm{SiO}_{4}^{2-} \\
\mathrm{B} 1\end{array}$ & $\begin{array}{l}5 \mu \mathrm{mol} \mathrm{L}-1 \\
5 \mu \mathrm{mol} \mathrm{L}-1 \\
1 \mu \mathrm{mol} \mathrm{L}-1 \\
5 \mu \mathrm{mol} \mathrm{L}-1 \\
600 \mathrm{pmol} \mathrm{L}^{-1}\end{array}$ \\
\hline 8. $\mathrm{I}+\mathrm{B} 12+\mathrm{B} 1$ & $\begin{array}{l}\mathrm{NO}_{3}^{-} \\
\mathrm{NH}_{4}^{+} \\
\mathrm{HPO}_{4}^{2-} \\
\mathrm{SiO}_{4}^{2-} \\
\mathrm{B} 12 \\
\mathrm{~B} 1\end{array}$ & $\begin{array}{l}5 \mu \mathrm{mol} \mathrm{L}{ }^{-1} \\
5 \mu \mathrm{mol} \mathrm{L}{ }^{-1} \\
1 \mu \mathrm{mol} \mathrm{L}{ }^{-1} \\
5 \mu \mathrm{mol} \mathrm{L}-1 \\
100 \mathrm{pmol} \mathrm{L}^{-1} \\
600 \mathrm{pmol} \mathrm{L}^{-1}\end{array}$ \\
\hline
\end{tabular}

for $20 \mathrm{~min}$ for the fixative to act on cells, immersed in liquid nitrogen for $15 \mathrm{~min}$ and frozen at $-80^{\circ} \mathrm{C}$. Abundance of prokaryotes was determined using a FACSCalibur flow cytometer equipped with a laser emitting at $488 \mathrm{~nm}$. Samples were stained with SYBR Green DNA fluorochrome, and bacterial abundance was detected by their signature of side scatter (SSC) and green fluorescence as described by Gasol and Del Giorgio (2000). The empirical calibration between light side scatter (SSC) and cell diameter described by Calvo-Díaz and Moran (2006) was used to estimate cell biovolume (BV). $\mathrm{BV}$ was converted into biomass by using the allometric factor of Norland (1993: $\mathrm{fg} \mathrm{C}_{\text {cell }}{ }^{-1}=120 \times \mathrm{BV}^{0.72}$ ) for the coastal experiments and using the open-ocean conversion factor for the oceanic experiments $\left(\mathrm{fg} \mathrm{C}\right.$ cell $\left.^{-1}=350 \times \mathrm{BV}\right)$.

\subsection{Nutrients}

Aliquots for inorganic-nutrient determinations (ammonium, nitrite, nitrate, phosphate and silicate) were collected before all other variables and directly from the Niskin bottle in order to avoid contamination. Polyethylene bottles $(50 \mathrm{~mL})$ precleaned with $5 \% \mathrm{HCl}$ were filled with the sample using contamination-free plastic gloves and immediately frozen at $-20^{\circ} \mathrm{C}$ until analysis using standard colorimetric methods with a Bran+Luebbe segmented flow analyzer (Hansen and Grasshoff, 1983). The detection limit was $0.1 \mu \mathrm{mol} \mathrm{L}{ }^{-1}$ for nitrate, $0.02 \mu \mathrm{mol} \mathrm{L}^{-1}$ for nitrite and phosphate, and $0.05 \mu \mathrm{mol} \mathrm{L}^{-1}$ for ammonium and silicate. Dissolved inorganic nitrogen (DIN) concentration was calculated as the sum of the ammonium, nitrite and nitrate concentrations.

\subsection{Vitamin B12}

Seawater samples for dissolved vitamin analysis were taken at surface and SCM depth on day 1, day 3 and day 5 in the coastal station and on day 1, day 3 and day 6 in the oceanic station of each cruise (Table S1 in the Supplement). Samples were filtered through $0.2 \mu \mathrm{m}$ Sterivex filters and frozen at $-20^{\circ} \mathrm{C}$ until further analysis. Samples $(1 \mathrm{~L})$ were preconcentrated using a solid-phase extraction with a $\mathrm{C} 18$ resin (Bondesil C18, Agilent) at pH 6.5 and rate of $1 \mathrm{~mL} \mathrm{~min}^{-1}$. Elution was performed with $12 \mathrm{~mL}$ of LCMS-grade methanol $(\mathrm{MeOH})$ that was removed via evaporation with nitrogen in a TurboVap. Gas pressure was initially set at 5 PSI and was slowly increased to 15 PSI until $300-500 \mu \mathrm{L}$ of sample remained. The concentrated samples were frozen at $-20^{\circ} \mathrm{C}$ until further analysis using liquid chromatography coupled to a mass spectrometry system.

The concentrate was filtered again through a $0.2 \mu \mathrm{m}$ cellular acetate membrane (Phenomenex) prior to the analysis. The ultra-performance liquid chromatography tandem mass spectrometry 3Q (UPLC-MS/MS) methodology was adapted from Sañudo-Wilhelmy et al. (2012), Heal et al. (2014) and Suffridge et al. (2017). Detection and quantification of dissolved vitamin B12 (cyanocobalamin and hydroxocobalamin) were conducted using an Agilent 1290 Infinity LC system (Agilent Technologies, Waghaeusel-Wiesental, Germany), coupled to an Agilent G6460A triple quadrupole mass spectrometer equipped with an Agilent Jet Stream ESI source. The LC system used a C18 reversed-phase-column Agilent Zorbax SB-C18 Rapid Resolution HT (2.1 mm inner diameter $\times 50 \mathrm{~mm}$ length, $1.8 \mu \mathrm{m}$ particle size) with a $100 \mu \mathrm{L}$ sample loop. Agilent Technologies software was used for data acquisition and analysis. Chromatographic separation was performed using LCMS-grade $\mathrm{MeOH}$ and water, both buffered to $\mathrm{pH} 5$ with $0.5 \%$ acetic acid, as mobile phases in a $15 \mathrm{~min}$ gradient, with the gradient starting at 
$7 \% \mathrm{MeOH}$ for 2 min, changing to $100 \% \mathrm{MeOH}$ by minute 11 , continuing at $100 \% \mathrm{MeOH}$ until $13.5 \mathrm{~min}$ and returning to initial conditions to complete $15 \mathrm{~min}$. Limits of detection (LODs) and limits of quantification (LOQs) were determined using sequential dilutions of the lowest point of the calibration curves. LODs were defined as the lowest detectable concentration of the analyte with a signal-tonoise $(\mathrm{S} / \mathrm{N})$ ratio for the qualitative transition of at least 3 . In the same way, LOQs were defined as the lowest quantifiable concentration with a $\mathrm{S} / \mathrm{N}$ ratio of 10 for the quantitative transition. $\mathrm{S} / \mathrm{N}$ ratios were calculated using the MassHunter Workstation software B.04.01. The LODs obtained were $0.04 \mathrm{pmol} \mathrm{L}^{-1}$ for hydroxocobalamin (OHB12) and $0.01 \mathrm{pmol} \mathrm{L}^{-1}$ for cyanocobalamin (CNB12), while the LOQs values were 0.05 and $0.025 \mathrm{pmol} \mathrm{L}^{-1}$ for OHB12 and $\mathrm{CNB} 12$, respectively. The average $\mathrm{B} 12$ recovery percentage after preconcentration and extraction of B-vitamin-spiked samples was $93 \%$. B-vitamin-free seawater was spiked with CNB12 and OHB12 standards for recovery percentage analysis. We failed to detect B1 vitamin in the preconcentrated samples, likely due to a low ambient concentration and low preconcentration volume.

\subsection{Microbial plankton community}

DNA samples were taken during the experimental period at surface and SCM depth in the coastal and oceanic stations. In particular, sampling of the microbial plankton community was carried out on day 0 , day 1 , day 3 and day 5 of each cruise. Community composition was assessed by sequencing the V4 and V5 regions from the 16S rRNA gene (16S rDNA) for prokaryotes and the V4 region from the 18S rRNA gene (18S rDNA) for eukaryotes. Two liters of water samples were sequentially filtered through $3 \mu \mathrm{m}$ pore size polycarbonate filters and a $0.2 \mu \mathrm{m}$ pore size Sterivex filter and immediately frozen in liquid nitrogen and conserved at $-80^{\circ} \mathrm{C}$. DNA retained in the 3 and $0.2 \mu \mathrm{m}$ filters was extracted by using the PowerSoil DNA isolation kit (MoBio Laboratories Inc., CA, USA) and the PowerWater DNA isolation kit (MoBio Laboratories Inc., CA, USA), respectively, according to the manufacturer's instructions. Prokaryotic DNA from $0.2 \mu \mathrm{m}$ filters was amplified using the universal primers $515 \mathrm{~F}$ and 926R (Parada et al., 2016) and eukaryotic DNA from both 3 and $0.2 \mu \mathrm{m}$ filters, using the primers TAReuk454FWD1 and TAReukREV3 (Logares et al., 2014). Amplified regions were sequenced in an Illumina MiSeq platform, and the sequences obtained were analyzed with the software package DADA2 (Callahan et al., 2016). The SILVA reference database (Quast et al., 2012) was used for taxonomic assignment of $16 \mathrm{~S}$ amplicon sequence variants (ASVs), and the PR2 (Guillou et al., 2013) and the marine protist database from the BioMarKs project (Massana et al., 2015) were used for taxonomic assignment of $18 \mathrm{~S}$ ASVs. The data for this study have been deposited in the European Nucleotide Archive (ENA) at EMBL-EBI (https: //www.ebi.ac.uk/ena, last access: 14 March 2020) under accession numbers PRJEB36188 (16S rDNA sequences) and PRJEB36099 (18S rDNA sequences). The ASV table is an analogue of the traditional OTU (operational taxonomic unit) table which records the number of times each exact amplicon sequence variant was observed in each sample (Callahan et al., 2016).

The raw ASV tables of prokaryotes and eukaryotes were subsampled to the number of reads present in the sample with the lowest number of reads, which was 2080 and 1286 for $16 \mathrm{~S}$ rDNA and $18 \mathrm{~S}$ rDNA, respectively. The abundance of ASVs was averaged for coastal and oceanic samples, differentiating between surface and SCM. A total of 1550 unique ASVs of prokaryotes were identified. As many ASVs of eukaryotes were present in both size fractions (e.g. those having a cell size range including $3 \mu \mathrm{m}$ ), we combined datasets derived from the 0.2 and the $3 \mu \mathrm{m}$ filters for eukaryotic community analyses. As explained in Hernández-Ruiz et al. (2018), we normalized the reads from each filter size using the filter DNA yield, as recommended in Dupont et al. (2015), obtaining 2293 unique ASVs. The sequence abundances of the subsampled ASV tables were transformed using the centered log ratio (clr) (Fernandes et al., 2014; Gloor et al., 2017). Before clr transformation, zeros were replaced by the minimum value that is larger than 0 divided by 2 (Aitchison, 1982; Martín-Fernández et al., 2003).

\subsection{Statistical analysis}

To compare the effect of different nutrient additions on the response variables, chlorophyll $a$ concentration and prokaryote biomass, we calculated response ratios (RR) by dividing each observation (mean of triplicates) of each treatment by the respective control treatment mean. A value equal to 1 implies no response, a value $<1$ implies a negative response and a value $>1$ implies growth stimulation after nutrient addition. Secondary limitation by B vitamins was calculated by dividing the mean value in the inorganic-nutrient and B-vitamin combined treatment by the mean value in the inorganic-nutrient-addition treatment. In the same way, a value $<1$ implies a negative effect of $B$ vitamins, and a value $>1$ implies the positive stimulation effect of B-vitamin treatment through secondary limitation.

Normal distribution was tested by a Kolmogorov-Smirnov test and non-normal variables such as temperature, salinity, DIN, $\mathrm{SiO}_{4}^{2-}$, and $\mathrm{Chl} a$ and $\mathrm{PB}$ response ratios were $\log$ transformed to attain normality. All statistical analyses were considered significant at the 0.05 significance level, and $p$ value was standardized as proposed by Good (1982) in order to overcome the low number of replicates. Differences between station and depth (spatial variability) and among sampling months (temporal variability) in the responses to $B$ vitamins were evaluated with factorial analysis of variance (ANOVA). Bonferroni post hoc tests analyses were conducted to test which treatments were significantly dif- 
ferent from the control treatment in each experiment. Nonmetric multidimensional scaling (nMDS) was used to analyze the similarities between the samples based on microbial assemblage structure using the PRIMER6 software (Clarke and Warwick, 2001; Clarke and Gorley, 2006). The similarities were evidenced in a multidimensional space by plotting more similar samples closer together. Analysis of similarity (ANOSIM) was used to verify that microbial community compositions from the same season and station were more similar to each other than to communities from a different season and station. A $Z$ test was used to test if averaged B-vitamin response ratios were significantly different from 1. The RELATE analysis implemented in PRIMER6 was used to relate the B-vitamin response patterns (BrayCurtis resemblance matrix built from phytoplankton and bacteria response ratios) with (1) environmental factors (Euclidean resemblance matrix built from normalized values of ammonium, nitrite, nitrate, phosphate, silicate, B12, temperature, salinity, Chl $a$ and prokaryote biomass), (2) prokaryote community composition (Euclidean resemblance matrix built form clr-transformed sequence abundance of major taxonomic groups) or (3) eukaryote community composition (Euclidean resemblance matrix built form clr-transformed sequence abundance of major taxonomic groups). RELATE calculates the Spearman rank correlations (Rho) between two resemblance matrices, and the significance is tested by a permutation test (999 permutations). In order to highlight which specific taxonomic groups are associated with changes of microbial plankton (prokaryote plankton and phytoplankton) responses to vitamin B1 and B12, we conducted a distance-based redundancy analysis (dbRDA) combined with a distance-based linear model (DistLM) using a stepwise procedure and adjusted $R^{2}$ as selection criteria using the PRIMER6 software.

\section{Results}

\subsection{Initial conditions}

Different hydrographic conditions were found during each cruise (Figs. 1 and 2). In February, heavy rainfall (Fig. 1c) combined with relaxed winds caused a halocline at $10 \mathrm{~m}$ depth (Fig. 2m). High levels of Chl $a$ (as derived from the calibrated CTD fluorescence sensor) were observed at the coastal station, being maximum $\left(4.97 \mu \mathrm{g} \mathrm{L}^{-1}\right)$ by the end of the cruise (Fig. 2a). At the oceanic station, Chl $a$ levels remained low (less than $3 \mu \mathrm{g} \mathrm{L}^{-1}$ ) throughout the cruise, being slightly higher in the subsurface layer (Fig. 2d).

Strong precipitation during the April cruise (Fig. 1c) caused a persistent surface halocline at the coastal station (Fig. 2n). Maximum Chl $a$ concentrations ranged from 0.99 to $2.73 \mu \mathrm{g} \mathrm{L}^{-1}$, declining from day 5 onwards (Fig. 2b) and coinciding with an increase in water temperature associated with a downwelling situation. At the oceanic station, a per- sistent subsurface Chl $a$ maximum (up to $1.61 \mu \mathrm{g} \mathrm{L}^{-1}$ ) was observed throughout the cruise (Fig. 2e).

In August, strong thermal stratification was observed at both stations (Fig. 2i and 1). At the beginning of the cruise, high Chl $a$ concentration (close to $20 \mu \mathrm{g} \mathrm{L}^{-1}$ ) was observed in subsurface water (Fig. 2c). Chl $a$ was relatively low at the oceanic station and increased by the end of the sampling period (Fig. 2f) as a consequence of an upwelling event (Fig. 1b) that brought cold and nutrient-rich water to the surface, at day 5 .

Abiotic and biotic conditions at the beginning of each experiment are shown in Fig. 3 and in Table S2. Overall, the concentration of dissolved inorganic nitrogen (DIN) was higher at the coastal than at the oceanic station, where very low levels were measured in August (Fig. 3i). At the coastal station, higher DIN concentrations were observed in surface compared to subsurface waters. The DIN : DIP (dissolved inorganic phosphorous) ratio was always lower in open ocean than in the coastal station and mostly below the Redfield ratio (16: 1). Phosphorous limitation (DIN : DIP $>16$ ) was frequent in coastal surface waters in February and April (Fig. 3j and $\mathrm{k}$ ).

On average, Chl $a$ concentration varied greatly between stations and months but was always higher at the coastal than at the oceanic station (Fig. 3a-c). Prokaryote biomass (PB) increased from winter (February) to summer (August) at the two stations (Fig. 3d-f). In February, Chl $a$ concentrations increased by the end of the cruise at both coastal and oceanic stations (Fig. 3a), while PB remained very low throughout this sampling period (Fig. 3d). In April, both PB and Chl $a$ were similar in the ocean and the coast and showed reduced temporal variability (Fig. $3 \mathrm{~b}$ and e), irrespective of the observed nutrient variability (Fig. 3h). In August, Chl $a$ concentration was much higher at the coastal than at the oceanic station and showed reduced temporal variability (except at the SCM in the coast) (Fig. 3c). At the beginning of the sampling period, $\mathrm{PB}$ was higher in the ocean than in the coast and tended to decline by the end of the cruise (Fig. 3f).

A MDS analysis revealed that microbial community composition showed a relatively reduced variability within this period, with samples clustering according to the sampling period (ANOSIM, $p=0.001$ ) and station (ANOSIM, $p=$ 0.001) (Fig. S1 in the Supplement). Consequently, we averaged the microbial community composition for each period and sampling site. The sampling period-averaged composition of the eukaryote community showed a clear variability among cruises, while differences between sampling locations and depths were less pronounced (Fig. 4a). At the coastal location, Mamiellophyceae (Ostreococcus and Micromonas) were relatively abundant in February and April, but their relative abundance sharply decreased in August. By contrast, the relative abundance of Dinophyceae was highest in August at both sampling locations. The contribution of diatoms (Bacillariophyta) was very low in summer at the oceanic station, and marine alveolates (MALV) groups 

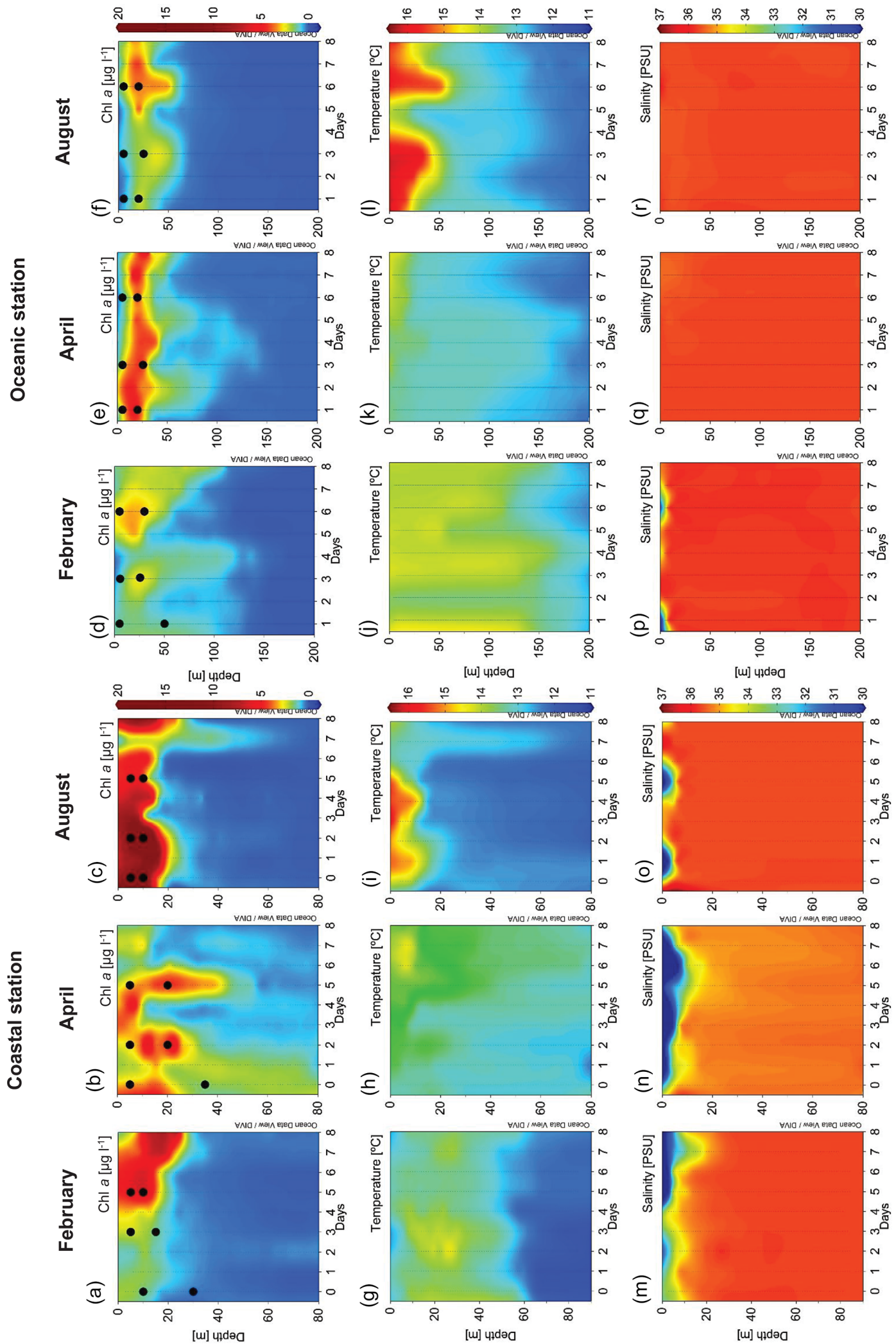

Figure 2. Vertical distribution over time in the coastal station of Chl $a\left(\mu \mathrm{g} \mathrm{L}{ }^{-1}\right)$ in (a) February, (b) April and (c) August; temperature $\left({ }^{\circ} \mathrm{C}\right)$ in (g) February, (h) April and (i) August; and salinity (PSU) in (m) February, (n) April and (o) August. Vertical distribution over time in the oceanic station of Chl $a\left(\mu \mathrm{g} \mathrm{L}{ }^{-1}\right)$ in (d) February, (e) April and (f) August; temperature $\left({ }^{\circ} \mathrm{C}\right)$ in (j) February, (k) April and (l) August; and salinity (PSU) in (p) February, (q) April and (r) August. Dots show the $t 0$ of the experiments. Chl $a$ : chlorophyll $a$ concentration. 


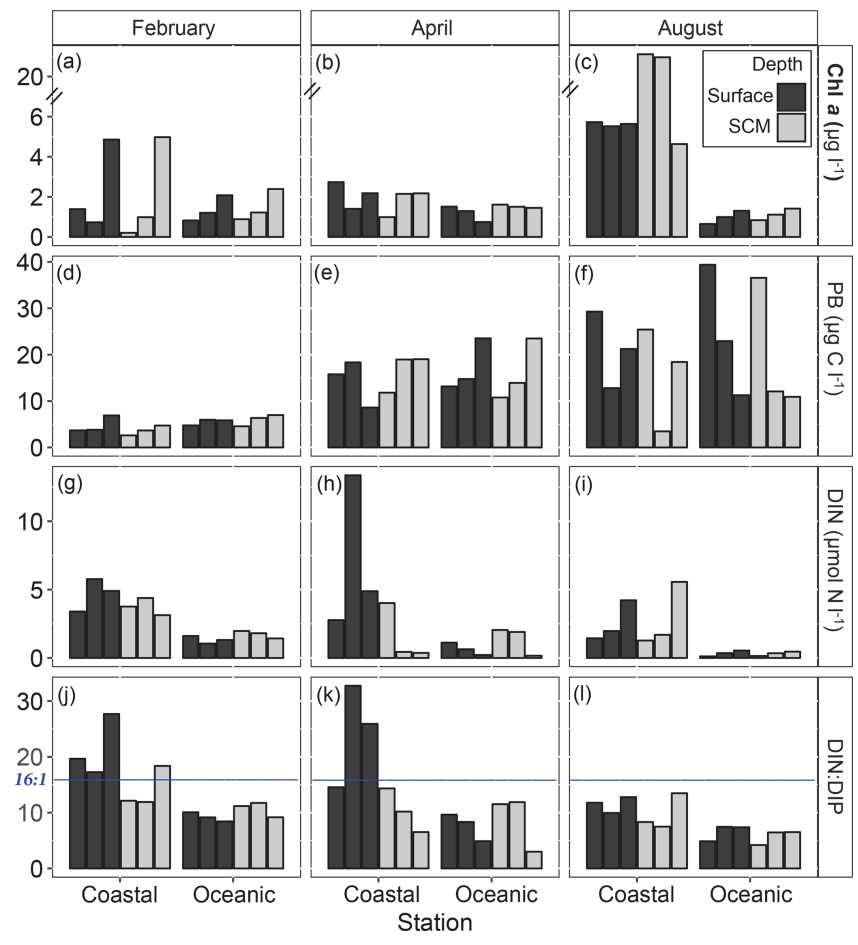

Figure 3. Initial biological conditions and abiotic factors at the coastal and oceanic sampling stations. Each bar corresponds to one of the three experiments performed at each depth and station during February, April and August. (a, b, c) Chl $a$, total Chl $a\left(\mu \mathrm{gL}^{-1}\right)$; note that the $y$ axis is broken. (d, e, f) $\mathrm{PB}$, prokaryote biomass $\left(\mu \mathrm{g} \mathrm{C} \mathrm{L}^{-1}\right)$. (g, h, i) DIN, dissolved inorganic nitrogen $\left(\mu \mathrm{mol} \mathrm{L} \mathrm{L}^{-1}\right)$. $(\mathbf{j}, \mathbf{k}, \mathbf{l})$ DIN : DIP, inorganic nitrogen : phosphate ratio. The blue line shows the Redfield ratio (16:1) and SCM refers to the subsurface chlorophyll maximum. Chl $a$ : chlorophyll $a$ concentration.

(MALV-I and MALV-II) were most representative in February at both locations. Flavobacteriales and Rhodobacterales were the dominant prokaryotes (Fig. 4b) in coastal waters, particularly in August, when both represented more than $80 \%$ of sequences, while the Cyanobacteria Synechococcus were mostly present in February and April. In oceanic waters, Flavobacteriales and Synechococcus were the dominant prokaryotes. The SAR11 clade and Archaea (Euryarchaeota and Thaumarchaeota) were most abundant in February at both sampling locations.

B12 concentration was low, ranging from 0.06 to $0.66 \mathrm{pmol} \mathrm{L}^{-1}$ (Table S1). Average B12 concentration was significantly higher in the coast $\left(0.30 \pm 0.13 \mathrm{pmol} \mathrm{L}^{-1}\right)$ than in the ocean $\left(0.15 \pm 0.12 \mathrm{pmol} \mathrm{L}^{-1}\right)(t$ test, $t=3.17, \mathrm{~d} f=$ $10, p=0.01)$ and showed less variability at the coastal than at the oceanic station (Fig. 4c).
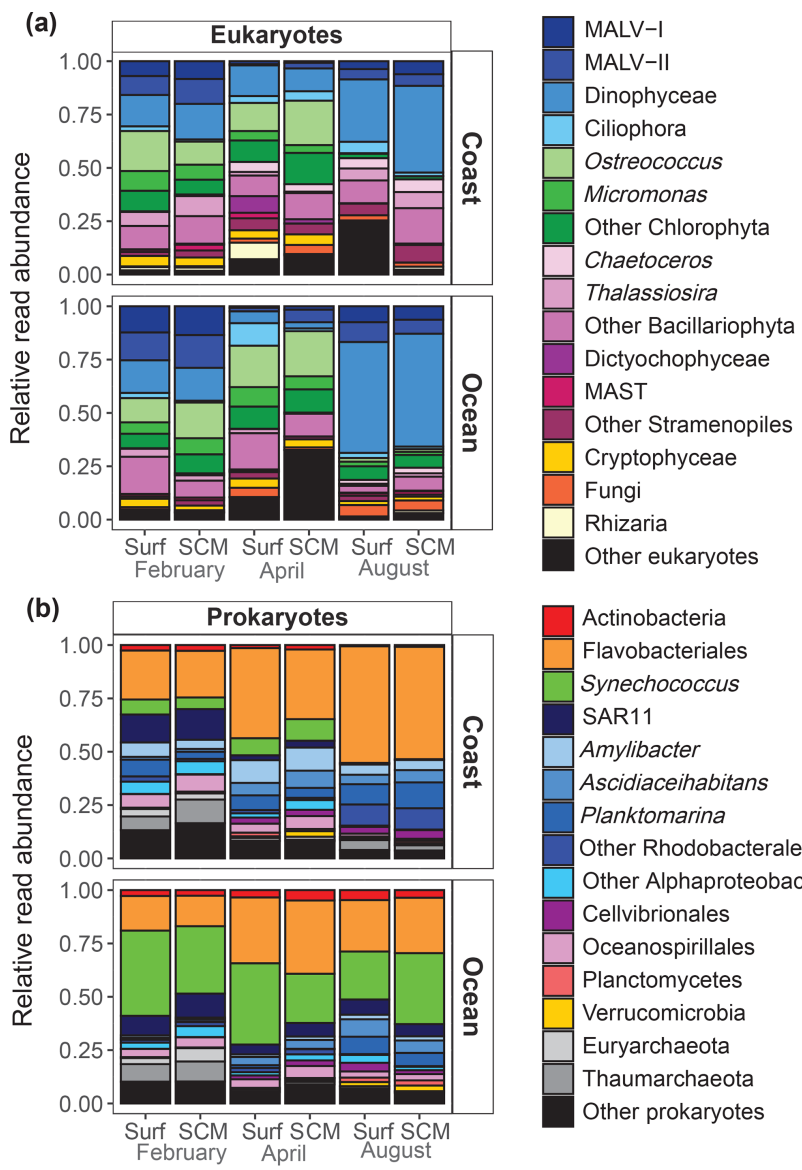

Actinobacteria Flavobacteriales Synechococcus SAR11 Amylibacter Ascidiaceihabitans Planktomarina Other Rhodobacterales Other Alphaproteobacteria Cellvibrionales Oceanospirillales Planctomycetes Verrucomicrobia Euryarchaeota Thaumarchaeota Other prokaryotes

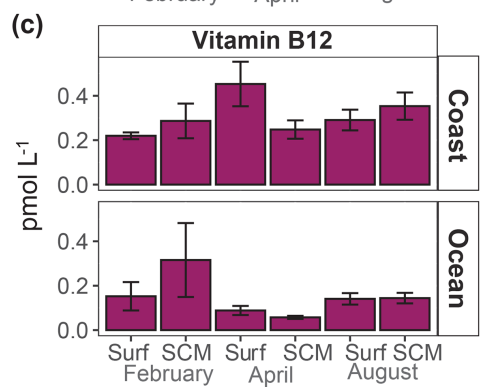

Figure 4. Averaged relative contribution of reads to the major taxonomic groups of (a) eukaryotes and (b) prokaryotes at surface (surf) and SCM depth in the coastal and oceanic stations in February, April and August. (c) Averaged B12 concentration $\left(\mathrm{pmol} \mathrm{L}^{-1}\right)$ at surface (surf) and SCM depth in the coastal and oceanic stations in February, April and August. Error bars represent standard error. SCM refers to the subsurface chlorophyll maximum.

\subsection{Short-term phytoplankton and prokaryote responses to inorganic-nutrient and vitamin additions}

The temporal development of the phytoplankton (as estimated from changes in $\mathrm{Chl} a$ concentration) and prokaryote biomass in the control treatments showed different patterns. Chl $a$ remained either stable or increased after $72 \mathrm{~h}$ of incuba- 
(a)

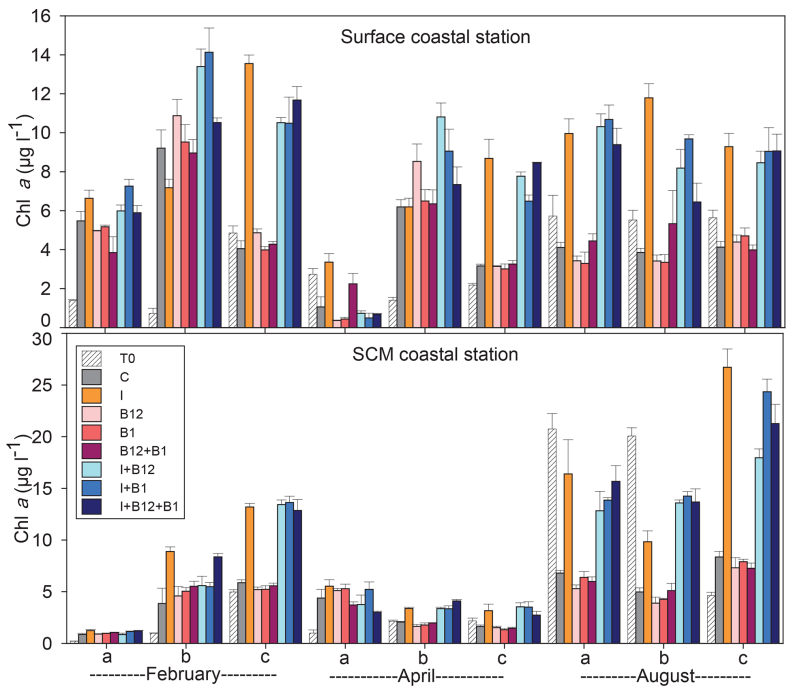

(c)

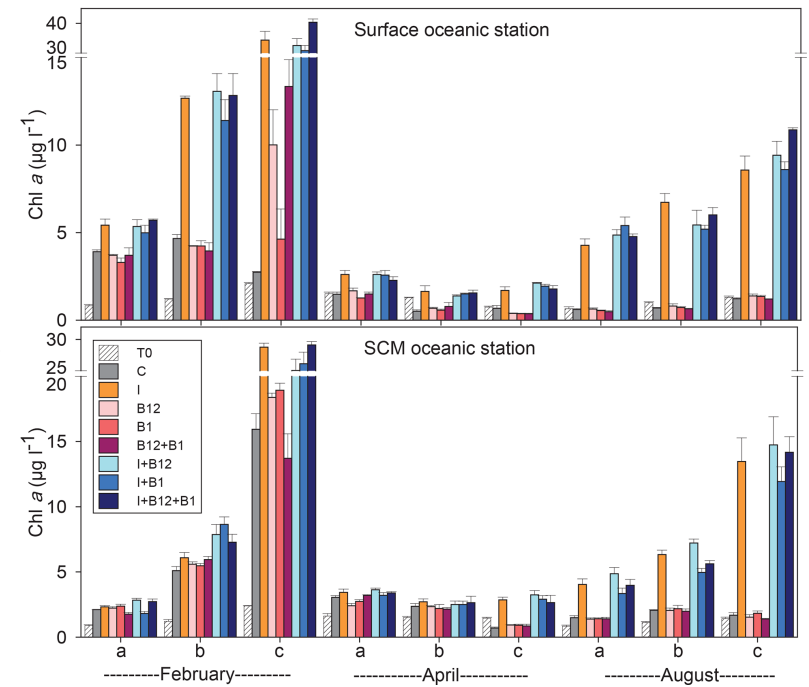

Figure 5. Chlorophyll $a$ concentration $\left(\mu \mathrm{g} \mathrm{L}^{-1}\right)$ in the $t 0$ of each experiment (striped bars) and in the endpoint of each treatment (colored bars) in the experiments conducted at (a) surface and (b) SCM depth in the coastal station and at (c) surface and (d) SCM depth in the oceanic station in February, April and August. Error bars represent standard error. Note that the $y$ axis is broken. SCM: subsurface chlorophyll maximum.

tion in $87.5 \%$ of the experiments conducted in February and April. However, $\mathrm{Chl} a$ mostly decreased in the coastal experiments conducted in August (Fig. 5a and c). A very similar pattern was observed for prokaryote biomass, although the decrease in biomass occurred both in the coastal and in the oceanic stations during summer (Fig. 6).

The response ratios (RRs) of $\mathrm{Chl} a$ and prokaryote biomass were calculated as a measure of the magnitude of phytoplankton and prokaryote responses to nutrient and vitamin treatments (Figs. S2, S3 and S4). The RRs differed between sampling stations (ANOVA, $F$ $(1502)=18.059, p<0.001)$ and among sampling periods (a)

(b)

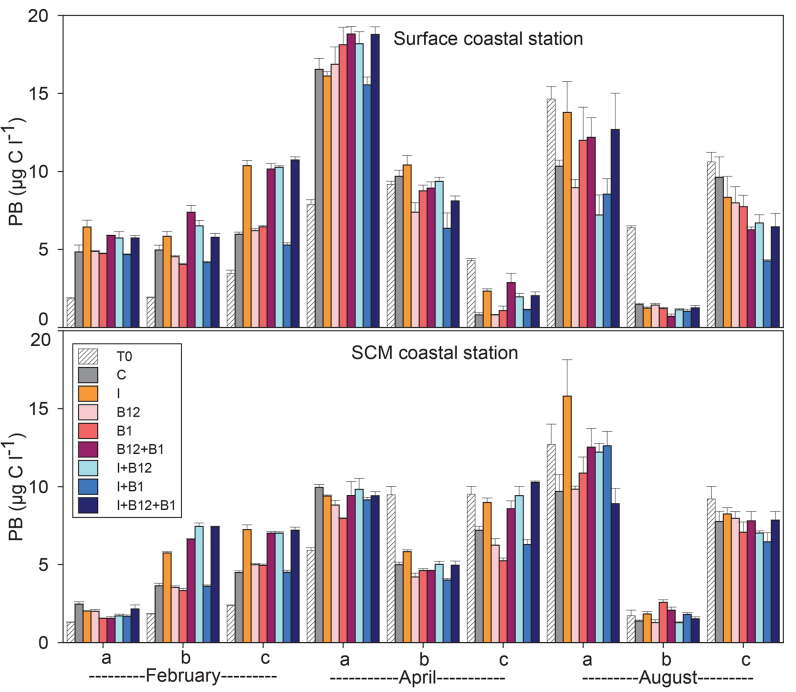

(c)

(d)

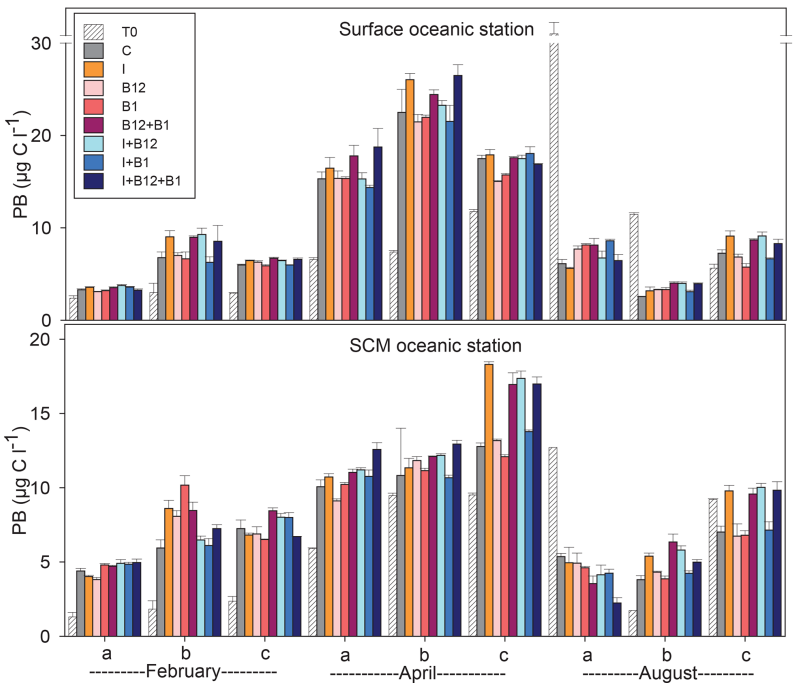

Figure 6. Prokaryote biomass $\left(\mu \mathrm{g} \mathrm{CL}^{-1}\right)$ in the $t 0$ of each experiment (striped bars) and in the endpoint of each treatment (colored bars) in the experiments conducted at (a) surface and (b) SCM depth in the coastal station and at (c) surface and (d) SCM depth in the oceanic station in February, April and August. Error bars represent standard error. Note that the $y$ axis is broken. SCM: subsurface chlorophyll maximum.

(ANOVA, $F(2501)=6.54, p=0.002)$. The most prominent responses of phytoplankton, compared to the control treatment, occurred after inorganic-nutrient amendments, especially in surface oceanic waters (Figs. 5c and S2b, f and j). The magnitude of the phytoplankton response to inorganic nutrients was significantly higher in oceanic than in coastal waters (ANOVA, $F(1,34)=5.22, p=0.028)$. Prokaryotes responded less than phytoplankton to inorganic nutrients and, in addition, heterotrophic prokaryote responses to inorganic nutrients were similar between coastal and oceanic waters (ANOVA, $F(1,34)=1.68, p=0.203)$. The addition of inorganic nutrients caused significant increases in Chl $a$ in 31 
out of the 36 experiments (Figs. 5 and S2), while prokaryotes increased their biomass in 19 out of 36 experiments (Figs. 6 and $\mathrm{S} 2$ ).

The addition of B12 stimulated phytoplankton in 5 out of 36 experiments (Figs. 5 and S3) and prokaryotes in 6 experiments (Figs. 6 and S4). Chl $a$ increased in 3 and prokaryote biomass in 7 out of 36 experiments after adding B1 (Figs. 5 and 6). B vitamins also caused negative responses of phytoplankton (Figs. 5 and S3) and prokaryote biomass (Figs. 6 and S4). The addition of vitamins induced decreases of Chl $a$ in 6 experiments (4 after adding B12 and 2 after adding B1) and prokaryote biomass in 14 experiments ( 6 after adding B12 and 8 after adding B1). Secondary limitation by B1 and/or B12 was occasionally observed when inorganic nutrients were limiting, leading to a higher biomass increase in the treatments including both inorganic nutrients and vitamins as compared to the inorganic-nutrient addition alone (Figs. 5, 6, S3 and S4). In the case of Chl $a$, secondary limitation by $\mathrm{B}$ vitamins was found in the $\mathrm{C}$-b-surface, Oc-a-SCM and Oc-b-SCM experiments in February; in the C-b-surface and C-b-SCM experiments in April; and in the C-b-SCM, Oc-b-SCM and Oc-c-surface experiments in August (Fig. 5).

In order to quantify the relevance of interday variability, we calculated the mean coefficient of variation $(\mathrm{CV})$ of the responses to $\mathrm{B}$ vitamins (i.e., excluding the responses to inorganic nutrients and normalizing the responses of the nutrient and vitamin combined treatments to the corresponding response to inorganic nutrients alone) within sampling periods for each sampling point (2 stations and 2 depths). The CV ranged from $9 \%$ in subsurface oceanic waters in April to $34 \%$ in surface coastal waters in April, averaging $16 \pm 6$ (SD) \% (data not shown). Considering that short-term (within sampling period) variability was overall very low, as well as for simplicity, we averaged the responses to B vitamins in the three experiments conducted at each of the 12 sampling points to further describe spatial and temporal patterns in the response to B-vitamin amendments (Fig. 7).

When averaging the responses within each sampling point (Fig. 7), some general patterns emerge. Both phytoplankton and prokaryotes showed more negative than positive responses to B1 and/or B12 amendments. Most positive responses occurred at the oceanic station $(83.3 \%)$, while negative responses dominated in the coast $(61.5 \%)$. Phytoplankton significant positive responses mostly occurred in February, showing an average increase of up to 1.2-fold in coastal subsurface waters after B12 + B1 amendment (Fig. 7a). The largest significant increase in $\mathrm{Chl} a$ (ca. 1.4-fold) occurred in April after the combined addition of B12 and B1 in coastal surface waters. Significant positive prokaryote responses mainly occurred in August, when the largest increase (ca. 1.3-fold) occurred in coastal subsurface waters after B1 amendment (Fig. 7b). Most positive responses were associated with treatments containing B12 either alone or combined with B1 (Fig. 7b). Phytoplankton primary B1 limitation was only found at the oceanic SCM in February
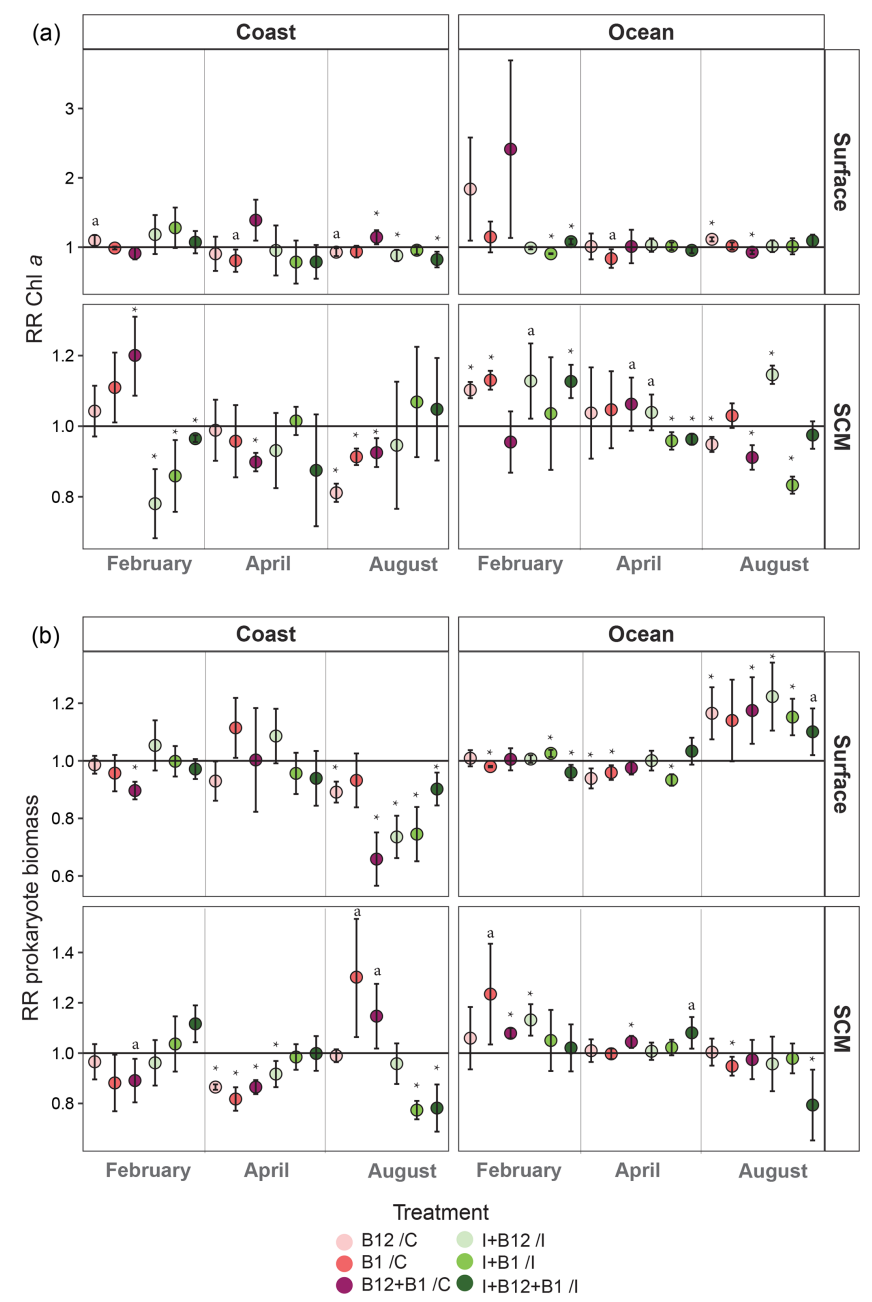

Figure 7. Monthly averaged response ratio (RR) of (a) Chl $a$ or (b) prokaryote biomass at surface and SCM depth in the coastal and oceanic stations. The horizontal line represents a response equal to 1 , which means no change relative to control in the pink dots (treatments with vitamins alone) and no change relative to inorganic (I) treatment in the green dots (vitamins combined with I treatments). Asterisks indicate averaged RRs that were significantly different from 1 ( $Z$ test; ${ }^{*} p<0.05$ ), and "a" labels indicate averaged RRs that were marginally significant ( $Z$ test; ${ }^{\mathrm{a}} p=0.05-0.06$ ). Error bars represent standard error. SCM: subsurface chlorophyll maximum.

(Fig. 7a), while prokaryote primary B1 limitation only occurred at the coastal SCM in August. In addition, prokaryote secondary B1 limitation occurred in oceanic surface waters in February and August.

\subsection{B-vitamin response patterns in relation to environmental factors and prokaryote and eukaryote community composition}

In order to explore the controlling factors of the observed B-vitamin response patterns, the correlation between the B- 
vitamin response resemblance matrix and the corresponding resemblance matrices obtained from the initial environmental factors, the initial prokaryotic community composition or the initial eukaryotic community composition was calculated. While eukaryotic community composition did not show a significant correlation with the B-vitamin responses (Spearman Rho $=0.05, p=0.39$ ), the prokaryotic community composition was significantly correlated with the Bvitamin responses (Spearman Rho $=0.31, p=0.041$ ). We then used distance-based linear modeling (DistLM) to identify the prokaryotic taxa which best explained the microbial plankton responses to B vitamins (Fig. 8). The resulting model explained $78 \%$ of the variation and included seven prokaryotic groups: Planktomarina (24\%), Actinobacteria (14\%), SAR11 $(8.2 \%)$, Cellvibrionales $(8.5 \%)$, Euryarchaeota (8.7\%), Flavobacteriales $(9 \%)$ and Synechococcus $(6.1 \%)$. The sequential test identified Planktomarina and Actinobacteria as the taxa explaining the largest fraction of variation (ca. $24 \%$ and $14 \%$, respectively, data not shown). The total variation explained by the dbRDA1 $(34.9 \%)$ and dbRDA2 $(24.5 \%)$ was $59.4 \%$, both represented as the $x$ and $y$ axis, respectively (Fig. 8). The dbRDA1 axis separated, to some extent, coastal samples, where negative responses to B vitamins dominated, from oceanic samples, where most positive responses were found (Fig. 7). The dbRDA plot showed that Cellvibrionales and Planktomarina positively correlated with axis 1, while SAR11 and Synechococcus showed negative correlation with axis 1 . Flavobacteriales and Actinobacteria mostly correlated with the dbRDA2 axis.

\section{Discussion}

Although the dependence of phytoplankton on B vitamins has been previously observed in cultures (e.g. Croft et al., 2006; Droop, 2007; Tang et al., 2010) and in natural microbial assemblages in coastal areas (e.g. Sañudo-Wilhelmy et al., 2006; Gobler et al., 2007; Koch et al., 2011, 2012; Barber-Lluch et al., 2019), this is, to the best of our knowledge, the most complete study about responses of phytoplankton and prokaryotes to vitamin-B12 and/or B1 addition. The 36 experiments developed in this study contributed to increasing our understanding of the role of vitamins B12 and B1 at different spatial and temporal scales.

Considering the high short-time variability of the hydrographic conditions in the area (Alvarez-Salgado et al., 1996), we expected a large interday variation in the responses to Bvitamin amendments. By contrast, interday variability of microbial responses to B vitamins and microbial plankton community composition was relatively small (Figs. 5, 6, S1 and $\mathrm{S} 2)$. The reduced short-term variability in the responses to Bvitamin additions suggested that $B$-vitamin availability might be controlled by factors operating at larger temporal scales, such as the succession of microbial communities associated with seasonal environmental variation (Hernández-Ruiz et

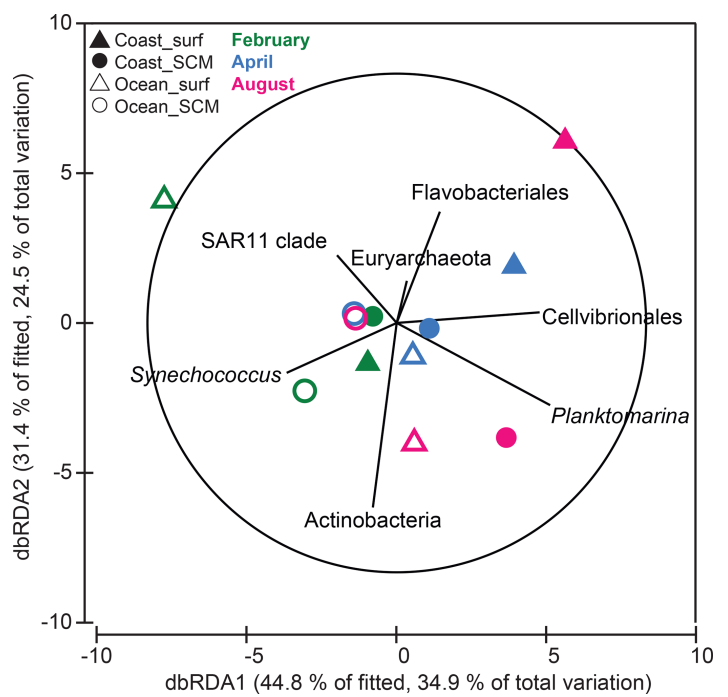

Figure 8. Distance-based redundancy analysis (dbRDA) of Bvitamin responses by phytoplankton and prokaryotes based on Bray-Curtis similarity. Only prokaryotic taxa that explained variability in the B-vitamin response structure selected in the DistLM model (step-wise procedure with adjusted $R^{2}$ criterion) were fitted to the ordination. Filled and open symbols represent samples from coastal and oceanic stations, respectively; triangles and circles represent samples from the surface and SCM, respectively; and colors correspond to the months of (green) February, (blue) April and (pink) August. SCM: subsurface chlorophyll maximum.

al., 2018; Hernando-Morales et al., 2018). Considering this, and for further discussion, we averaged the responses from the three experiments conducted during each sampling period, resulting in 12 experimental situations ( 2 stations $\times 2$ depths $\times 3$ periods). Overall, phytoplankton and/or prokaryote growth enhancement in at least one B-vitamin treatment was frequent but relatively small in this productive ecosystem, showing 1.1-fold to 1.3 -fold increases in $75 \%$ of the experimental situations for phytoplankton and in $50 \%$ for prokaryotes. On the other hand, negative responses to at least one B-vitamin treatment occurred in $83 \%$ of the experimental situations for phytoplankton and in $67 \%$ for prokaryotes (Fig. 7). The low and constant B12 ambient concentration (Fig. 4c) and the reduced magnitude of microbial responses suggest a close balance between production and consumption of this growth factor. Different patterns of response to B-vitamin amendments were observed in phytoplankton and prokaryotes (Fig. 7), which appear to be mostly explained by the prokaryotic community composition (Fig. 8).

\subsection{Positive responses to vitamin-B1 and $\mathrm{B} 12$ amendments}

The experimental design allowed the detection of two categories of B-vitamin dependency of the microbial plankton community. A primary limitation by B vitamins occurs when microorganisms respond to additions of $\mathrm{B}$ vitamins alone. 
A secondary limitation by $\mathrm{B}$ vitamins arises when the response to the combined addition of B vitamins and inorganic nutrients is significantly higher than that to inorganic nutrients alone. Such a response occurs because of the ambient B-vitamin depletion associated with the plankton growth after inorganic-nutrient enrichment. Most positive ( $72 \%$ for phytoplankton and $60 \%$ for prokaryotes) responses occurred after single B-vitamin additions, suggesting that inorganicnutrient availability enhances B-vitamin production by the prototrophic microbes. Under nutrient-limiting conditions, the external supply of vitamins could reduce the energy costs associated with its synthesis (Jaehme and Slotboom, 2015), stimulating the growth not only of auxotrophs but also of prototrophs.

The significant positive effects of B12 and/or B1 addition suggest that these compounds may be eventually limiting microbial growth in marine productive ecosystems, as previously observed by other authors (e.g., Panzeca et al., 2006; Sañudo-Wilhelmy et al., 2006; Bertrand et al., 2007; Gobler et al., 2007; Koch et al., 2011, 2012; Barber-Lluch et al., 2019). Most positive responses to B-vitamin amendments were observed in oceanic waters, where B12 concentration was significantly lower than in coastal waters (Fig. 4c). Unfortunately we lack B1 measurements in this study, but, according to previous field studies in other oceanographic regions, a similar pattern to that observed for B12 can be expected (Cohen et al., 2017; Sañudo-Wilhelmy et al., 2012; Suffridge et al., 2018). The overall low and stable concentration of B12 at both sampling locations suggests a high turnover time of this compound in these productive, welllit waters. Rapid cycling of B12 in surface waters may occur due to high biological uptake rates (Taylor and Sullivan, 2008; Koch et al., 2012) and/or photochemical degradation (Carlucci et al., 1969; Juzeniene and Nizauskaite, 2013; Juzeniene et al., 2015). The measured B12 concentrations were in the lower range reported for coastal sites and similar to that found in the upwelling system off the California coast in the San Pedro Basin during winter, spring and summer (Panzeca et al., 2009).

The increase of Chl $a$ was mostly associated with B12 amendments, which is consistent with the known incapability of eukaryotes to synthesize this vitamin (Croft et al., 2005; Tang et al., 2010; Sañudo-Wilhelmy et al., 2014). Considering the very low concentration of B12 in the sampling area, the relatively limited phytoplankton response to B vitamins suggests that the existing species might have adapted to overcome B12 shortage. For example, changes in external B12 availability may cause shifts from vitamin-B12 dependence to vitamin-B12 independence in taxa possessing the vitamin-B12-independent methionine synthase (MetE) gene (Bertrand et al., 2013; Helliwell et al., 2014). Other strategies used by phytoplankton to cope with low B12 concentration include increased cobalamin acquisition machinery, decreased cobalamin demand, and management of reduced methionine synthase activity through changes in folate and S- adenosyl methionine metabolism (Bertrand et al., 2012). The available data on B12 half-saturation constants for phytoplankton (0.1-10 $\left.\mathrm{pmol} \mathrm{L}^{-1}\right)$ (Droop, 1968, 2007; Taylor and Sullivan, 2008; Tang et al., 2010; Koch et al., 2011) are similar to or higher than the $\mathrm{B} 12$ concentrations measured here $\left(0.3 \mathrm{pmol} \mathrm{L}^{-1}\right.$ in the coastal and $0.15 \mathrm{pmol} \mathrm{L}^{-1}$ in the oceanic waters, on average), reinforcing the hypothesis of a phytoplankton community adapted to B12-limited concentrations in this upwelling system.

The positive responses of phytoplankton in surface oceanic waters in February seemed to be associated with high abundance of Synechococcus and SAR11 (Figs. 4b and 8). Synechococcus produce a B12 analog known as pseudocobalamin, where the lower ligand base adenine replaces 5,6-dimethylbenzimidazole (DMB) (Helliwell et al., 2016). In natural conditions, pseudocobalamin is considerably less bioavailable to eukaryotic algae than other cobalamin forms (Helliwell et al., 2016; Heal et al., 2017). SAR11 do not require B12 and do not have pathways for its synthesis (Sañudo-Wilhelmy et al., 2014; Gómez-Consarnau et al., 2018), suggesting that B12 synthesis could be limited in oceanic waters in winter due to the low abundance of potential B12 producers.

Microbial responses to B vitamins in subsurface oceanic waters in February were associated with high abundance of Synechococcus and, to some extent, of Actinobacteria (Fig. 8). In these experiments, positive effects of B1 addition on phytoplankton and prokaryotes were observed (Fig. 7). While Synechococcus is capable of B1 synthesis (Carini et al., 2014; Sañudo-Wilhelmy et al., 2014; GómezConsarnau et al., 2018), Actinobacteria seems to have a strong dependence on this vitamin (Gómez-Consarnau et al., 2018). Among the sequenced eukaryote genomes, only Stramenopiles contain genes coding for the synthesis of thiamine monophosphate (Sañudo-Wilhelmy et al., 2014; Cohen et al., 2017). While Stramenopiles, dominated by Bacillariophyta, were ubiquitous in the sampling area, their relative contribution was lower in oceanic waters (Fig. 4a). The simultaneous stimulation of phytoplankton and prokaryotes by B1 addition in subsurface oceanic waters in winter suggests a strong demand for this compound under these particular conditions; however, what triggers the observed responses remain unclear.

Even though B1 caused a significant effect on phytoplankton only in subsurface waters in winter, half of the positive responses of prokaryotes were associated with B1 supply (Fig. 7b). This pattern is consistent with the recently described widespread dependence of bacterioplankton on external B1 supply (Paerl et al., 2018). B1 stimulated prokaryote growth in subsurface coastal waters and surface oceanic waters in summer (Fig. 7b), when the B-vitamin response patterns were associated with high abundance of Planktomarina and Actinobacteria (Fig. 8), which are expected to strongly depend on external B1 sources (Giebel et al., 2013; Gómez-Consarnau et al., 2018). The generalized significant 
and positive responses of prokaryotes to vitamin treatments in surface oceanic waters in summer, when the prokaryote biomass was high and dissolved-inorganic-nitrogen concentration was very low (Fig. 3i), suggest that prokaryotes may have an advantage in the uptake and assimilation of B vitamins under nitrogen-limiting conditions. This is consistent with the observation of small $(0.7-3 \mu \mathrm{m})$ plankton cells containing more B1 than larger cells (Fridolfsson et al., 2019). Following this, it has been speculated that bacteria and small phytoplankton can transfer B1 to large cells through predation by acting as an important source of this compound in the marine environment (Fridolfsson et al., 2019).

\subsection{Negative responses to vitamin-B1 and B12 amendments}

Similar experiments conducted in this area also reported negative responses of microbial plankton to vitamin-B12 additions (Barber-Lluch et al., 2019). The predominantly negative prokaryote responses after vitamin amendments in the coast during summer (Fig. 7b), when nutrient concentrations were low (Fig. 3), suggest either a strong competition between phytoplankton and prokaryotes or a stimulation of predation. Dinoflagellates were particularly abundant in summer at both sampling sites and depths. Many dinoflagellate species are auxotrophs for B1 and/or B12 (Croft et al, 2006; Tang et al., 2010), and also many of them are phagotrophs (Stoecker and Capuzzo, 1990; Smayda, 1997; Sarjeant and Taylor, 2006; Stoecker et al., 2017); thus the external supply of B vitamins may have promoted their growth, ultimately leading to net decreases in microbial biomass at the end of the experiments. Several studies demonstrated that vitamin B12 is implicated in the occurrence of dinoflagellate blooms around the world (Aldrich, 1962; Carlucci and Bowes, 1970; Takahashi and Fukazawa, 1982; Yu and Rong-cheng, 2000). It has been suggested that the B12dependent enzyme methylmalonyl-CoA mutase in dinoflagellate, euglenoid and heterokont algae allows them to grow heterotrophically when B12 is available (Croft et al., 2006). Therefore, the B12 enrichment could trigger such a nutritional strategy, particularly in summer, when mineral nutrients are less available, resulting in an increased predation pressure on prokaryotes.

The B-vitamin response patterns in surface coastal waters in summer (Fig. 7) seemed to be associated with high abundance of Flavobacteriales (Fig. 8). All isolates of Bacteroidetes sequenced so far are predicted to be B12 auxotrophs (Sañudo-Wilhelmy et al., 2014; Gómez-Consarnau et al., 2018), and recent metatranscriptomic analyses reveal that B1 synthesis gene transcripts are relatively low in Flavobacteria as a group (Gómez-Consarnau et al., 2018). As both phytoplankton and prokaryotes are dominated by potentially B12 and B1 auxotrophs (dinoflagellates and Flavobacteriales) in the coast during summer (Fig. 4b), the negative responses could be the result of strong competition for B vitamins. However, the negative responses to $B$ vitamins of both phytoplankton and prokaryotes in surface coastal water in summer suggest an increase in phytoplankton and prokaryote predation by mixotrophs rather than competition between them. By contrast, prokaryotes and phytoplankton showed opposite patterns of response to B vitamins in subsurface coastal waters in summer, which suggests competition between both microbial compartments (Fig. 7). While phytoplankton negatively responded only to single B-vitamin additions, prokaryotes responded negatively only when both inorganic nutrients and B vitamins were added (Fig. 7). It is conceivable that phytoplankton had an advantage over prokaryotes when mineral nutrients were added. This hypothesis contrasts with previous studies reporting that B12- and B1vitamin uptake is dominated by picoplankton (Koch et al., 2011, 2012), strongly suggesting that bacteria could outcompete larger phytoplankton for vitamin uptake. By contrast, Koch et al. (2014) found that carbon-specific B12 uptake by large phytoplankton was significantly lower during nonbloom (low nutrient concentration) compared to bloom conditions (high nutrient concentration), which suggests better competitive ability under nutrient-rich conditions.

\section{Conclusions}

In conclusion, our findings suggest that the heterogeneous responses of microbial plankton to B1- and B12-vitamin supply in this coastal upwelling system could be partially controlled by the composition of the prokaryote community, which is consistent with their previously reported major role as $\mathrm{B} 12$ producers and $\mathrm{B} 1$ consumers. Even though we lack data on B1 concentration, the overall moderate responses together with the low ambient B12 concentration suggest that the microbial plankton community in this area could be well adapted to cope with B-vitamin shortage and that a close balance exists between production and consumption of these important growth factors.

Data availability. The data for this study have been deposited in the European Nucleotide Archive (ENA) at EMBL-EBI (https: //www.ebi.ac.uk/ena, EMBL-EBI, 2020) under accession numbers PRJEB36188 (16S rDNA sequences) and PRJEB36099 (18S rDNA sequences). Other data are available upon request from the corresponding author (Vanessa Joglar).

Supplement. The supplement related to this article is available online at: https://doi.org/10.5194/bg-17-2807-2020-supplement.

Author contributions. ET designed the experiments and VJ carried them out with contributions from all coauthors. VJ analyzed the data, VJ and ET interpreted the results, and VJ prepared the manuscript under ET supervision. 
Competing interests. The authors declare that they have no conflict of interest.

Acknowledgements. We thank all the people involved in the project ENVISION for helping with sampling and analytical work. We also thank the crew of the B/O Ramón Margalef for their help during the work at sea. From IIM-CSIC, Vanessa Vieitez and Maria José Pazó performed the nutrient analyses. Vanessa Joglar was supported by an FPI fellowship from the Spanish Ministry of Economy and Competitiveness.

Financial support. This research has been supported by the Spanish Ministry of Economy and Competitiveness through the ENVISION (CTM2014-59031-P) and INTERES (CTM2017-83362-R) projects.

Review statement. This paper was edited by Koji Suzuki and reviewed by three anonymous referees.

\section{References}

Aitchison, J.: The Statistical Analysis of Compositional Data, J. R. Stat. Soc. Ser. B, 44, 139-160, https://doi.org/10.1111/j.25176161.1982.tb01195.x, 1982.

Aldrich, D.: Photoautotrophy in Gymnodinium breve Davis, Science, 137, 988-990, https://doi.org/10.1126/SCIENCE.137.3534.988, 1962.

Alvarez-Salgado, X. A., Rosón, G., Pérez, F. F., and Pazos, Y.: Hydrographic variability off the Rías Baixas (NW Spain) during the upwelling season, J. Geophys. Res., 98, 14447, https://doi.org/10.1029/93JC00458, 1993.

Alvarez-Salgado, X. A., Rosón, G., Pérez, F. F., Figueiras, F. G., and Pazos, Y.: Nitrogen cycling in an estuarine upwelling system, the Ria de Arousa (NW Spain). I. Short-time-scale patterns of hydrodynamic and biogeochemical circulation, Mar. Ecol. Prog. Ser., 135, 259-273, https://doi.org/10.3354/meps135259, 1996.

Amin, S. A., Parker, M. S., and Armbrust, E. V.: Interactions between Diatoms and Bacteria, Microbiol. Mol. Biol. Rev., 76, 667-684, https://doi.org/10.1128/MMBR.00007-12, 2012.

Arrigo, K. R.: Marine microorganisms and global nutrient cycle, Nature, 437, 349-355, https://doi.org/10.1038/nature04159, 2005.

Barber-Lluch, E., Hernández-Ruiz, M., Prieto, A., Fernández, E., and Teira, E.: Role of vitamin B12 in the microbial plankton response to nutrient enrichment, Mar. Ecol. Prog. Ser., 626, 29-42, https://doi.org/10.3354/meps13077, 2019.

Barton, E. D., Largier, J. L., Torres, R., Sheridan, M., Trasviña, A., Souza, A., Pazos, Y., and Valle-Levinson, A.: Coastal upwelling and downwelling forcing of circulation in a semienclosed bay: Ria de Vigo, Prog. Oceanogr., 134, 173-189, https://doi.org/10.1016/j.pocean.2015.01.014, 2015.

Bertrand, E. M. and Allen, A. E.: Influence of vitamin B auxotrophy on nitrogen metabolism in eukaryotic phytoplankton, Front. Microbiol., 3, 1-16, https://doi.org/10.3389/fmicb.2012.00375, 2012.
Bertrand, E. M., Saito, M. A., Rose, J. M., Riesselman, C. R., Lohan, M. C., Noble, A. E., Lee, P. A., and DiTullio, G. R.: Vitamin B12 and iron colimitation of phytoplankton growth in the Ross Sea, Limnol. Oceanogr., 52, 1079-1093, https://doi.org/10.4319/lo.2007.52.3.1079, 2007.

Bertrand, E. M., Allen, A. E., Dupont, C. L., Norden-Krichmar, T. M., Bai, J., Valas, R. E., and Saito, M. A.: Influence of cobalamin scarcity on diatom molecular physiology and identification of a cobalamin acquisition protein, P. Natl. Acad. Sci. USA, 109, E1762-E1771, https://doi.org/10.1073/pnas.1201731109, 2012.

Bertrand, E. M., Moran, D. M., McIlvin, M. R., Hoffman, J. M., Allen, A. E., and Saito, M. A.: Methionine synthase interreplacement in diatom cultures and communities: Implications for the persistence of B12 use by eukaryotic phytoplankton, Limnol. Oceanogr., 58, 1431-1450, https://doi.org/10.4319/lo.2013.58.4.1431, 2013.

Browning, T. J., Achterberg, E. P., Rapp, I., Engel, A., Bertrand, E. M., Tagliabue, A., and Moore, C. M.: Nutrient co-limitation at the boundary of an oceanic gyre, Nature, 551, 242-246, https://doi.org/10.1038/nature24063, 2017.

Browning, T. J., Rapp, I., Schlosser, C., Gledhill, M., Achterberg, E. P., Bracher, A., and Le Moigne, F. A. C.: Influence of Iron, Cobalt, and Vitamin B12 Supply on Phytoplankton Growth in the Tropical East Pacific During the 2015 El Niño, Geophys. Res. Lett., 45, 6150-6159, https://doi.org/10.1029/2018GL077972, 2018.

Callahan, B. J., McMurdie, P. J., Rosen, M. J., Han, A. W., Johnson, A. J. A., and Holmes, S. P.: DADA2: High-resolution sample inference from Illumina amplicon data, Nat. Methods, 13, 581583, https://doi.org/10.1038/nmeth.3869, 2016.

Calvo-Díaz, A. and Moran, X. A. G.: Seasonal dynamics of picoplankton in shelf waters of the southern Bay of Biscay, Aquat. Microb. Ecol., 42, 159-174, https://doi.org/10.3354/ame042159, 2006.

Carini, P., Campbell, E. O., Morré, J., Sañudo-Wilhelmy, S. A., Cameron Thrash, J., Bennett, S. E., Temperton, B., Begley, T., and Giovannoni, S. J.: Discovery of a SAR11 growth requirement for thiamin's pyrimidine precursor and its distribution in the Sargasso Sea, ISME J., 8, 1727-1738, https://doi.org/10.1038/ismej.2014.61, 2014.

Carlucci, A. F. and Bowes, P. M.: Vitamin production and utilization by phytoplankton in mixed culture, J. Phycol., 6, 393-400, https://doi.org/10.1111/j.1529-8817.1970.tb02413.x, 1970.

Carlucci, A. F., Silbernagel, S. B., and McNally, P. M.: Influence of temeprature and solar radiation on persistence of vitamin B12, thiamine and biotin in seawater, J. Phycol., 5, 302-305, https://doi.org/10.1111/j.1529-8817.1969.tb02618.x, 1969.

Clarke, K. and Warwick, R.: A further biodiversity index applicable to species lists: variation in taxonomic distinctness, Mar. Ecol. Prog. Ser., 216, 265-278, https://doi.org/10.3354/meps216265, 2001.

Clarke, K. R., and Gorley, R. N.: PRIMER v6: Usermanual/tutorial, PRIMER-E, Plymouth, UK, 2006.

Cohen, N. R., A. Ellis, K., Burns, W. G., Lampe, R. H., Schuback, N., Johnson, Z., Sañudo-Wilhelmy, S., and Marchetti, A.: Iron and vitamin interactions in marine diatom isolates and natural assemblages of the Northeast Pacific Ocean, Limnol. Oceanogr., 62, 2076-2096, https://doi.org/10.1002/lno.10552, 2017. 
Cooper, M. B. and Smith, A. G.: Exploring mutualistic interactions between microalgae and bacteria in the omics age, Curr. Opin. Plant Biol., 26, 147-153, https://doi.org/10.1016/j.pbi.2015.07.003, 2015.

Croft, M. T., Lawrence, A. D., Raux-Deery, E., Warren, M. J., and Smith, A. G.: Algae acquire vitamin B12 through a symbiotic relationship with bacteria, Nature, 438, 90-93, https://doi.org/10.1038/nature04056, 2005.

Croft, M. T., Warren, M. J., and Smith, A. G.: Algae need their vitamins, Eukaryot. Cell, 5, 1175-1183, https://doi.org/10.1128/EC.00097-06, 2006.

Cruz-López, R. and Maske, H.: The vitamin B1 and B12 required by the marine dinoflagellate Lingulodinium polyedrum can be provided by its associated bacterial community in culture, Front. Microbiol., 7, 1-13, https://doi.org/10.3389/fmicb.2016.00560, 2016.

Cullen, J. J., Neale, P. J., and Lesser, M. P.: Biological weighting function for the inhibition of phytoplankton photosynthesis by ultraviolet radiation, Science., 258, 646-650, https://doi.org/10.1126/science.258.5082.646, 1992.

Droop, M. R.: Vitamin B12 and Marine Ecology, IV. The Kinetics of Uptake, Growth and Inhibition in Monochrysis Lutheri, J. Mar. Biol. Assoc. United Kingdom, 48, 689-733, https://doi.org/10.1017/S0025315400019238, 1968.

Droop, M. R.: Vitamins, phytoplankton and bacteria: Symbiosis or scavenging?, J. Plankton Res., 29, 107-113, https://doi.org/10.1093/plankt/fbm009, 2007.

Dupont, C. L., Mccrow, J. P., Valas, R., Moustafa, A., Walworth, N., Goodenough, U., Roth, R., Hogle, S. L., Bai, J., Johnson, Z. I., Mann, E., Palenik, B., Barbeau, K. A., Craig Venter, J., and Allen, A. E.: Genomes and gene expression across light and productivity gradients in eastern subtropical Pacific microbial communities, ISME J., 9, 1076-1092, https://doi.org/10.1038/ismej.2014.198, 2015.

EMBL-EBI: European Nucleotide Archive, available at: https:// www.ebi.ac.uk/ena, last access: 14 March 2020.

Fernandes, A. D., Reid, J., Macklaim, J. M., McMurrough, T. A., Edgell, D. R., and Gloor, G. B.: Unifying the analysis of high-throughput sequencing datasets: characterizing RNAseq, 16S rRNA gene sequencing and selective growth experiments by compositional data analysis, Microbiome, 2, 1-15, https://doi.org/10.1186/2049-2618-2-15, 2014.

Field, C. B., Field, C. B., Behrenfeld, M. J., and Randerson, J. T.: Primary Production of the Biosphere: Integrating Terrestrial and Oceanic Components, Science, 281, 237-240, https://doi.org/10.1126/science.281.5374.237, 1998.

Figueiras, F. G., Abarta, U., and Fernández Reiriz, M. J.: Coastal upwelling, primary production and mussel growth in the Rías Baixas of Galicia, Hydrobiologia, 484, 121-131, https://doi.org/10.1023/A:1021309222459, 2002.

Fraga, F.: Upwelling off the Galacian Coast, northwest Spain, in: Coastal and Estuarine Sciences, edited by: Richards, F. A., 176182,1981

Fridolfsson, E., Bunse, C., Legrand, C., Lindehoff, E., Majaneva, S., and Hylander, S.: Seasonal variation and species-specific concentrations of the essential vitamin B 1 (thiamin) in zooplankton and seston, Mar. Biol., 166, 1-13, https://doi.org/10.1007/s00227019-3520-6, 2019.
Fuhrman, J. A., Steele, J. A., Hewson, I., Schwalbach, M. S., Brown, M. V., Green, J. L., and Brown, J. H.: A latitudinal diversity gradient in planktonic marine bacteria, P. Natl. Acad. Sci. USA, 105, 7774-7778, https://doi.org/10.1073/pnas.0803070105, 2008.

Gasol, J. M. and Del Giorgio, P. A.: Using flow cytometry for counting natural planktonic bacteria and understanding the structure of planktonic bacterial communities, Sci. Mar., 64, 197-224, https://doi.org/10.3989/scimar.2000.64n2197, 2000.

Giebel, H. A., Kalhoefer, D., Gahl-Janssen, R., Choo, Y. J., Lee, K., Cho, J.-C., Tindall, B. J., Rhiel, E., Beardsley, C., Aydogmus, O. O., Voget, S., Daniel, R., Simon, M., and Brinkhoff, T.: Planktomarina temperata gen. nov., sp. nov., belonging to the globally distributed RCA cluster of the marine Roseobacter clade, isolated from the German Wadden Sea, Int. J. Syst. Evol. Microbiol., 63, 4207-4217, https://doi.org/10.1099/ijs.0.053249-0, 2013.

Gloor, G. B., Macklaim, J. M., Pawlowsky-Glahn, V., and Egozcue, J. J.: Microbiome datasets are compositional: And this is not optional, Front. Microbiol., 8, 1-6, https://doi.org/10.3389/fmicb.2017.02224, 2017.

Gobler, C. J., Norman, C., Panzeca, C., Taylor, G. T., and SañudoWilhelmy, S. A.: Effect of B-vitamins (B1, B12) and inorganic nutrients on algal bloom dynamics in a coastal ecosystem, Aquat. Microb. Ecol., 49, 181-194, https://doi.org/10.3354/ame01132, 2007.

Gómez-Consarnau, L., Sachdeva, R., Gifford, S. M., Cutter, L. S., Fuhrman, J. A., Sañudo-Wilhelmy, S. A., and Moran, M. A.: Mosaic patterns of B-vitamin synthesis and utilization in a natural marine microbial community, Environ. Microbiol., 20, 28092823, https://doi.org/10.1111/1462-2920.14133, 2018.

Gonzalez-Nuevo, G., Gago, J., and Cabanas, J. M.: Upwelling index: A powerful tool for marine research in the NW Iberian upwelling system, J. Oper. Oceanogr., 7, 47-57, https://doi.org/10.1080/1755876X.2014.11020152, 2014.

Good, I. J.: Standardized tail-area probabilities, J. Stat. Comput. Simul., 16, 65-66, https://doi.org/10.1080/00949658208810607, 1982.

Grant, M. A., Kazamia, E., Cicuta, P., and Smith, A. G.: Direct exchange of vitamin B12 is demonstrated by modelling the growth dynamics of algal-bacterial cocultures, ISME J., 8, 1418-1427, https://doi.org/10.1038/ismej.2014.9, 2014.

Guillou, L., Bachar, D., Audic, S., Bass, D., Berney, C., Bittner, L., Boutte, C., Burgaud, G., de Vargas, C., Decelle, J., del Campo, J., Dolan, J. R., Dunthorn, M., Edvardsen, B., Holzmann, M., Kooistra, W. H. C. F., Lara, E., Le Bescot, N., Logares, R., Mahé, F., Massana, R., Montresor, M., Morard, R., Not, F., Pawlowski, J., Probert, I., Sauvadet, A.-L., Siano, R., Stoeck, T., Vaulot, D., Zimmermann, P., and Christen, R.: The Protist Ribosomal Reference database (PR2): a cata$\log$ of unicellular eukaryote Small Sub-Unit rRNA sequences with curated taxonomy, Nucl. Acid. Res., 41, D597-D604, https://doi.org/10.1093/nar/gks1160, 2013.

Haines, K. C. and Guillard, R. R. L.: Growth of vitamin B12requiring marine diatoms in mixed laboratory cultures with vitamin B12-producing marine bacteria, J. Phycol., 10, 245-252, https://doi.org/10.1111/j.1529-8817.1974.tb02709.x, 1974.

Hallegraeff, G. M.: A review of harmful algal blooms and their apparent global increase, Phycologia, 32, 79-99, https://doi.org/10.2216/i0031-8884-32-2-79.1, 1993. 
Hansen, H. P. and Grasshoff, K.: Automated chemical analysis, in: Methods of Seawater Analysis, edited by: Grasshoff, K., Ehrhardt, M., and Kremling, K., 2nd Edn., Verlag Chemie, Deerfield Beach, 347-395, 1983.

Heal, K. R., Carlson, L. T., Devol, A. H., Armbrust, E. V., Moffett, J. W., Stahl, D. A., and Ingalls, A. E.: Determination of four forms of vitamin B12 and other B vitamins in seawater by liquid chromatography/tandem mass spectrometry, Rapid Commun. Mass Sp., 28, 2398-2404, https://doi.org/10.1002/rcm.7040, 2014.

Heal, K. R., Qin, W., Ribalet, F., Bertagnolli, A. D., CoyoteMaestas, W., Hmelo, L. R., Moffett, J. W., Devol, A. H., Armbrust, E. V., Stahl, D. A., and Ingalls, A. E.: Two distinct pools of B12 analogs reveal community interdependencies in the ocean, P. Natl. Acad. Sci. USA, 114, 364-369, https://doi.org/10.1073/pnas.1608462114, 2017.

Helliwell, K. E., Wheeler, G. L., Leptos, K. C., Goldstein, R. E., and Smith, A. G.: Insights into the evolution of vitamin B12 auxotrophy from sequenced algal genomes, Mol. Biol. Evol., 28, 29212933, https://doi.org/10.1093/molbev/msr124, 2011.

Helliwell, K. E., Scaife, M. A., Sasso, S., Paula, A., Araujo, U., Purton, S., and Smith, A. G.: Unraveling vitamin B12responsive gene regulation in algae, Plant Physiol., 165, 388397, https://doi.org/10.1104/pp.113.234369, 2014.

Helliwell, K. E., Lawrence, A. D., Holzer, A., Kudahl, U. J., Sasso, S., Kräutler, B., Scanlan, D. J., Warren, M. J., and Smith, A. G.: Cyanobacteria and eukaryotic algae use different chemical variants of vitamin B12, Curr. Biol., 26, 999-1008, https://doi.org/10.1016/j.cub.2016.02.041, 2016.

Hernández-Ruiz, M., Barber-Lluch, E., Prieto, A., Álvarez-Salgado, X. A., Logares, R., and Teira, E.: Seasonal succession of small planktonic eukaryotes inhabiting surface waters of a coastal upwelling system, Environ. Microbiol., 20, 2955-2973, https://doi.org/10.1111/1462-2920.14313, 2018.

Hernando-Morales, V., Varela, M. M., Needham, D. M., Cram, J., Fuhrman, J. A., and Teira, E.: Vertical and Seasonal Patterns Control Bacterioplankton Communities at Two Horizontally Coherent Coastal Upwelling Sites off Galicia (NW Spain), Microb. Ecol., 76, 866-884, https://doi.org/10.1007/s00248-018-1179-z, 2018.

Jaehme, M. and Slotboom, D. J.: Diversity of membrane transport proteins for vitamins in bacteria and archaea, Biochim. Biophys. Acta-Gen. Subj., 1850, 565-576, https://doi.org/10.1016/J.BBAGEN.2014.05.006, 2015.

Juzeniene, A. and Nizauskaite, Z.: Photodegradation of cobalamins in aqueous solutions and in human blood, J. Photochem. Photobiol. B, 122, 7-14, https://doi.org/10.1016/j.jphotobiol.2013.03.001, 2013.

Juzeniene, A., Baturaite, Z., Lagunova, Z., Grigalavicius, M., Porojnicu, A. C., Bruland, Ø. S., and Moan, J.: Influence of multiple UV exposures on serum cobalamin and vitamin D levels in healthy females, Scand. J. Public Health, 43, 324-330, https://doi.org/10.1177/1403494815572206, 2015.

Kazamia, E., Czesnick, H., Nguyen, T. T. Van, Croft, M. T., Sherwood, E., Sasso, S., Hodson, S. J., Warren, M. J., and Smith, A. G.: Mutualistic interactions between vitamin B12-dependent algae and heterotrophic bacteria exhibit regulation, Environ. Microbiol., 14, 1466-1476, https://doi.org/10.1111/j.14622920.2012.02733.x, 2012.
Koch, F., Marcoval, M. A., Panzeca, C., Bruland, K. W., SañudoWilhelmy, S. A., and Gobler, C. J.: The effect of vitamin B12 on phytoplankton growth and community structure in the Gulf of Alaska, Limnol. Oceanogr., 56, 1023-1034, https://doi.org/10.4319/lo.2011.56.3.1023, 2011.

Koch, F., Hattenrath-Lehmann, T. K., Goleski, J. A., SañudoWilhelmy, S., Fisher, N. S., and Gobler, C. J.: Vitamin B1 and B12 uptake and cycling by plankton communities in coastal ecosystems, Front. Microbiol., 3, 1-11, https://doi.org/10.3389/fmicb.2012.00363, 2012.

Koch, F., Burson, A., Tang, Y. Z., Collier, J. L., Fisher, N. S., Sañudo-Wilhelmy, S., and Gobler, C. J.: Alteration of plankton communities and biogeochemical cycles by harmful Cochlodinium polykrikoides (Dinophyceae) blooms, Harmful Algae, 33, 41-54, https://doi.org/10.1016/j.hal.2014.01.003, 2014.

Logares, R., Sunagawa, S., Salazar, G., Cornejo-Castillo, F. M., Ferrera, I., Sarmento, H., Hingamp, P., Ogata, H., de Vargas, C., Lima-Mendez, G., Raes, J., Poulain, J., Jaillon, O., Wincker, P., Kandels-Lewis, S., Karsenti, E., Bork, P., and Acinas, S. G.: Metagenomic 16S rDNA Illumina tags are a powerful alternative to amplicon sequencing to explore diversity and structure of microbial communities, Environ. Microbiol., 16, 2659-2671, https://doi.org/10.1111/1462-2920.12250, 2014.

Lorenzen, C. J. and Newton Downs, J.: The specific absorption coefficients of chlorophyllide a and pheophorbide a in $90 \%$ acetone, and comments on the fluorometric determination of chlorophyll and pheopigments1, Limnol. Oceanogr., 31, 449452, https://doi.org/10.4319/lo.1986.31.2.0449, 1986.

Madigan, M. T., Martinko, J., and Parker, J.: Brock Biology of Microorganisms, 11th Edn., Pearson Prentice Hall, Boston, p. 1019, 2005.

Martens, J. H., Barg, H., Warren, M., and Jahn, D.: Microbial production of vitamin B12, Appl. Microbiol. Biotechnol., 58, 275285, https://doi.org/10.1007/s00253-001-0902-7, 2002.

Martín-Fernández, J. A., Barceló-Vidal, C., and Pawlowsky-Glahn, V.: Dealing with zeros and missing values in compositional data sets using nonparametric imputation, Math. Geol., 35, 253-278, https://doi.org/10.1023/A:1023866030544, 2003.

Martínez-García, S., Fernández, E., Álvarez-Salgado, X. A., González, J., Lønborg, C., Marañón, E., Morán, X. A. G., and Teira, E.: Differential responses of phytoplankton and heterotrophic bacteria to organic and inorganic nutrient additions in coastal waters off the NW Iberian Peninsula, Mar. Ecol. Prog. Ser., 416, 17-33, https://doi.org/10.3354/meps08776, 2010a.

Martínez-García, S., Fernández, E., Calvo-Díaz, A., Marañón, E., Morán, X. A. G., and Teira, E.: Response of heterotrophic and autotrophic microbial plankton to inorganic and organic inputs along a latitudinal transect in the Atlantic Ocean, Biogeosciences, 7, 1701-1713, https://doi.org/10.5194/bg-7-17012010, 2010b

Massana, R., Gobet, A., Audic, S., Bass, D., Bittner, L., Boutte, C., Chambouvet, A., Christen, R., Claverie, J. M., Decelle, J., Dolan, J. R., Dunthorn, M., Edvardsen, B., Forn, I., Forster, D., Guillou, L., Jaillon, O., Kooistra, W. H. C. F., Logares, R., Mahé, F., Not, F., Ogata, H., Pawlowski, J., Pernice, M. C., Probert, I., Romac, S., Richards, T., Santini, S., Shalchian-Tabrizi, K., Siano, R., Simon, N., Stoeck, T., Vaulot, D., Zingone, A., and de Vargas, C.: Marine protist diversity in European coastal waters and sediments as revealed by high-throughput sequencing, En- 
viron. Microbiol., 17, 4035-4049, https://doi.org/10.1111/1462$2920.12955,2015$

Monteverde, D. R., Gómez-Consarnau, L., Suffridge, C., and Sañudo-Wilhelmy, S. A.: Life's utilization of B vitamins on early Earth, Geobiology, 15, 3-18, https://doi.org/10.1111/gbi.12202, 2017.

Moore, C. M., Mills, M. M., Arrigo, K. R., Berman-Frank, I., Bopp, L., Boyd, P. W., Galbraith, E. D., Geider, R. J., Guieu, C., Jaccard, S. L., Jickells, T. D., La Roche, J., Lenton, T. M., Mahowald, N. M., Marañón, E., Marinov, I., Moore, J. K., Nakatsuka, T., Oschlies, A., Saito, M. A., Thingstad, T. F., Tsuda, A., and Ulloa, O.: Processes and patterns of oceanic nutrient limitation, Nat. Geosci., 6, 701-710, https://doi.org/10.1038/ngeo1765, 2013.

Okbamichael, M. and Sañudo-Wilhelmy, S. A.: A new method for the determination of Vitamin B12 in seawater, Anal. Chim. Acta, 517, 33-38, https://doi.org/10.1016/J.ACA.2004.05.020, 2004.

Okbamichael, M. and Sañudo-Wilhelmy, S. A.: Direct determination of vitamin B1 in seawater by solid-phase extraction and high-performance liquid chromatography quantification, Limnol. Oceanogr. Method., 3, 241-246, https://doi.org/10.4319/lom.2005.3.241, 2005.

Paerl, R. W., Sundh, J., Tan, D., Svenningsen, S. L., Hylander, S., Pinhassi, J., Andersson, A. F., and Riemann, L.: Prevalent reliance of bacterioplankton on exogenous vitamin B1 and precursor availability, P. Natl. Acad. Sci. USA, 115, E10447-E10456, https://doi.org/10.1073/pnas.1806425115, 2018.

Panzeca, C., Tovar-Sanchez, A., Agustí, S., Reche, I., Duarte, C. M., Taylor, G. T., and Sañudo-Wilhelmy, S. A.: B vitamins as regulators of phytoplankton dynamics, EOS T. Am. Geophys. Un., 87, 4-6, https://doi.org/10.1029/2006EO520001, 2006.

Panzeca, C., Beck, A. J., Tovar-Sanchez, A., Segovia-Zavala, J., Taylor, G. T., Gobler, C. J., and Sañudo-Wilhelmy, S. A.: Distributions of dissolved vitamin B12 and Co in coastal and openocean environments, Estuar. Coast. Shelf Sci., 85, 223-230, https://doi.org/10.1016/j.ecss.2009.08.016, 2009.

Parada, A. E., Needham, D. M., and Fuhrman, J. A.: Every base matters: Assessing small subunit rRNA primers for marine microbiomes with mock communities, time series and global field samples, Environ. Microbiol., 18, 1403-1414, https://doi.org/10.1111/1462-2920.13023, 2016.

Pinhassi, J., Winding, A., Binnerup, S. J., Zweifel, U. L., Riemann, B., and Hagström, A.: Spatial variability in bacterioplankton community composition at the Skagerrak - Kattegat Front, Mar. Ecol. Prog. Ser., 255, 1-13, https://doi.org/10.3354/meps255001, 2003.

Quast, C., Pruesse, E., Yilmaz, P., Gerken, J., Schweer, T., Yarza, P., Peplies, J., and Glöckner, F. O.: The SILVA ribosomal RNA gene database project: improved data processing and web-based tools, Nucl. Acid. Res., 41, D590-D596, https://doi.org/10.1093/nar/gks1219, 2012.

Roth, J., Lawrence, J., and Bobik, T.: Cobalamin (coenzyme B12): synthesis and biological significance, Annu. Rev. Microbiol., 50, 137-181, https://doi.org/10.1146/annurev.micro.50.1.137, 1996.

Sañudo-Wilhelmy, S. A., Gobler, C. J., Okbamichael, M., and Taylor, G. T.: Regulation of phytoplankton dynamics by vitamin B12, Geophys. Res. Lett., 33, 10-13, https://doi.org/10.1029/2005GL025046, 2006.
Sañudo-Wilhelmy, S. A., Cutter, L. S., Durazo, R., Smail, E. A., Gomez-Consarnau, L., Webb, E. A., Prokopenko, M. G., Berelson, W. M., and Karl, D. M.: Multiple B-vitamin depletion in large areas of the coastal ocean, P. Natl. Acad. Sci. USA, 109, 14041-14045, https://doi.org/10.1073/pnas.1208755109, 2012.

Sañudo-Wilhelmy, S. A., Gómez-Consarnau, L., Suffridge, C., and Webb, E. A.: The role of B vitamins in marine biogeochemistry, Ann. Rev. Mar. Sci., 6, 339-367, https://doi.org/10.1146/annurev-marine-120710-100912, 2014.

Sarjeant, W. A. S. and Taylor, F. J. R.: The Biology of Dinoflagellates, Micropaleontology, 35, 191-192, https://doi.org/10.2307/1485469, 2006.

Smayda, T. J.: Harmful algal blooms: Their ecophysiology and general relevance to phytoplankton blooms in the sea, Limnol. Oceanogr., 42, 1137-1153, 1997.

Stoecker, D. K. and Capuzzo, J. M.: Predation on Protozoa: its importance to zooplankton, J. Plankton Res., 12, 891-908, https://doi.org/10.1093/plankt/12.5.891, 1990.

Stoecker, D. K., Hansen, P. J., Caron, D. A., and Mitra, A.: Mixotrophy in the Marine Plankton, Ann. Rev. Mar. Sci., 9, 311-335, https://doi.org/10.1146/annurev-marine-010816-060617, 2017.

Suffridge, C., Cutter, L., and Sañudo-Wilhelmy, S. A.: A new analytical method for direct measurement of particulate and dissolved B-vitamins and their congeners in seawater, Front. Mar. Sci., 4, 1-11, https://doi.org/10.3389/fmars.2017.00011, 2017.

Suffridge, C. P., Gómez-Consarnau, L., Monteverde, D. R., Cutter, L., Arístegui, J., Alvarez-Salgado, X. A., Gasol, J. M., and Sañudo-Wilhelmy, S. A.: B-vitamins and their congeners as potential drivers of microbial community composition in an oligotrophic marine ecosystem, J. Geophys. Res.-Biogeo., 123 , 2890-2907, https://doi.org/10.1029/2018JG004554, 2018.

Takahashi, M. and Fukazawa, N.: A mechanism of "red-tide" formation - II. Effect of selective nutrient stimulation on the growth of different phytoplankton species in natural water, Mar. Biol., 70, 267-273, https://doi.org/10.1007/BF00396845, 1982.

Tang, Y. Z., Koch, F., and Gobler, C. J.: Most harmful algal bloom species are vitamin B1 and B12 auxotrophs, P. Natl. Acad. Sci. USA, 107, 20756-20761, https://doi.org/10.1073/pnas.1009566107, 2010.

Taylor, G. T. and Sullivan, C. W.: Vitamin B12 and cobalt cycling among diatoms and bacteria in Antarctic sea ice microbial communities, Limnol. Oceanogr., 53, 1862-1877, https://doi.org/10.4319/lo.2008.53.5.1862, 2008.

van Dolah, F. M., Roelke, D., and Greene, R. M.: Health and Ecological Impacts of Harmful Algal Blooms: Risk Assessment Needs, Hum. Ecol. Risk Assess. An Int. J., 7, 1329-1345, https://doi.org/10.1080/20018091095032, 2001.

Warren, M. J., Raux, E., Schubert, H. L., and Escalante-Semerena, J. C.: The biosynthesis of adenosylcobalamin (vitamin B12), Nat. Prod. Rep., 19, 390-412, https://doi.org/10.1039/b108967f, 2002.

Yu, L. and Rong-cheng, L.: Research on red tide occurrences using enclosed experimental ecosystem in West $\mathrm{Xi}$ amen Harbor, China - Relationship between nutrients and red tide occurrence, Chin. J. Oceanol. Limnol., 18, 253-259, https://doi.org/10.1007/BF02842672, 2000. 